\title{
Drivers and Constraints of Land use Transitions on Western Grasslands: Insights from a California Mountain Ranching Community
}

Nicole Buckley Biggs ( $\square$ nbuck@stanford.edu )

Stanford University https://orcid.org/0000-0002-2635-7257

\section{Research Article}

Keywords: Land use transitions, landscape sustainability, ecosystem services, social-ecological systems, rangelands

Posted Date: September 21st, 2021

DOI: https://doi.org/10.21203/rs.3.rs-828586/v1

License: (c) (1) This work is licensed under a Creative Commons Attribution 4.0 International License.

Read Full License 


\section{Abstract}

Context. Land use change drives a host of sustainability challenges on Earth's grasslands. To understand the relationship between changing land use patterns, human well-being, and ecosystem services, research is needed into land use transitions on privately-owned grasslands. Such inquiry lies at the intersection of land system science and landscape sustainability science.

Objectives. This study investigated land use change in a mountain cattle ranching community in the Sierra Nevada, California. The research objective was to highlight the drivers and constraints of identified land use transitions and the types of landowners and policies influencing ecological outcomes.

Methods. This research used a mixed methods case study based on participant observation, 30 semistructured interviews, and analysis of land cover and real estate data from California's Farmland Monitoring and Mapping Program, USDA CropScape, and a local real estate sales database. Interviews were conducted with ranchers, public agencies, and conservation and real estate industry representatives, and analyzed with the constant comparison method using Nvivo 12.

Results. Land use transitions in the case study region include agricultural intensification, residential and solar development, and disintensification from amenity migration. These transitions were influenced by decreasing land access and water availability, remote work, intergenerational succession, and conservation policy.

Conclusions. By highlighting influences on working lands, this study can be applied to improve the uptake of conservation policies. For the future, several factors appear critical to conserving ecosystem services on private grasslands: ensuring grazing lands access, income diversification, groundwater regulations, agriculture-compatible conservation easements, and land use policies supporting ownership transition to amenity purposes rather than low-density residential development.

\section{Introduction}

Global grasslands are experiencing significant land use change, particularly conversion to cropland and residential development (Asner et al. 2004; Foley et al. 2005; White et al. 2000). In the continental US, a third of rangelands-landscapes dominated by grasses, forbs or shrubs-have been converted to alternative uses since European settlement (Rindfuss et al. 2007). While serving to meet growing human needs, conversion can degrade soils, deplete biodiversity (Lark et al. 2020; Sala et al. 2000), and reduce water quality and availability (Bourque et al. 2019). Such habitat loss, particularly for residential development on agricultural lands (Freedgood et al. 2020), has driven a 53\% reduction in US grassland bird populations since 1970 (Rosenberg et al. 2019). Converted grasslands support significantly fewer plant species than old-growth grasslands and require hundreds of thousands of years to recover species richness (Nerlekar and Veldman 2020). 
The pursuit of landscape sustainability, or long-term continuation of ecosystem services for human and environmental benefit (Wu 2013, 2021), requires understanding social-ecological drivers working across scales to shift land use (Bürgi et al. 2004; Geist and Lambin 2002; Lambin et al. 2001). Land system scientists and rangeland researchers have investigated global grassland conversion trends (e.g., desertification, land abandonment), yet further research is needed into the full suite of land use transitions taking place on privately-owned grasslands in developed economies. In particular, unknowns remain regarding the impacts of recent changes in grasslands ownership on land use and the effectiveness of environmental policies in these new social-ecological contexts.

To understand global land use transitions, researchers have developed the land use transition pathways framework identifying land trajectories from an undisturbed state to frontier usage, agricultural expansion and eventually urban development (Foley et al. 2005; DeFries et al. 2004; Mustard et al. 2007). Land use transitions are driven by decisions made by individuals, communities and governments based on evaluating trade-offs between meeting human needs and environmental impacts (DeFries and Eshleman, 2004). This research highlights how economic development can drive land use change toward both intensification and disintensification. Disintensification, for example, includes when economic development brings a transition from depleting towards conserving resources, as with protected areas or outsourcing of agricultural production (Lambin and Meyfroidt, 2010). Reduction or removal of agriculture from landscapes, referred to as "land abandonment," is becoming particularly prevalent in North America, the former Soviet Union, Asia, and the EU (Cramer et al. 2008; Plieninger et al. 2014).

An important land use transition underway in the American West is sale of rangelands to in-migrating hobbyist or "amenity" ranchers (Epstein et al. 2019; Gosnell et al. 2006; Gosnell and Travis 2005). Multifunctional agricultural landscapes like rangelands provide an array of non-commodity benefits to landowners, including socio-ecological, cultural and viewshed values (Brummel and Nelson 2014; Renting et al. 2009), which amenity ranchers value more than property income potential. While ranchers have historically been both consumption and production oriented (Smith and Martin 1972), amenity landowners are mostly uninterested in personally managing their grassland properties for commodity production and so transfer responsibility to ranch managers, lease their land for grazing, or eliminate agricultural activities altogether (Gosnell and Abrams 2011; Lubell et al. 2013). The rise of amenity ranchers can be thought of as increasing numbers of landowners living 'on the land, but not off the land.' Population movement into rural areas for lifestyle reasons-called the rural rebound (Ferranto et al. 2014) or rural gentrification (Abrams and Bliss 2013; Gosnell and Abrams 2011)-is predicted to continue across the American West as production ranchers subdivide their lands (Plieninger et al. 2012; Walker and Fortmann 2003).

Rangeland ownership change results from endogenous and exogenous factors functioning across scales, from international markets to local cultural shifts. Societal developments like remote work, decreased transportation costs, expansion of digital and service-oriented industries, and the popularization of romantic notions of rural life draw newcomers to rural areas (Gosnell and Abrams 2011; Jackson-Smith 2003). Other forces drive residents away from rural areas, such as government 
regulations and societal hostility to ranching (Farley et al. 2017; Hurst et al. 2017; Liffmann et al. 2000). Landownership change is also driven by loss of intergenerational succession, influenced by political and financial factors like accessibility of grazing allotments, state and federal tax codes, land use planning, and incentive programs like conservation easements (Brunson and Huntsinger 2008; Haggerty et al. 2018).

Amenity ranching is reshaping modern rural landscapes as in-migrating landowners introduce new mental models (Abrams and Bliss 2013). In this context, mental models are how individuals perceive and interpret the natural environment, in turn informing natural resource management (Denzau and North 1994, Jones et al. 2011). Different types of range landowners have distinct goals, capital access and time availability (Coppock and Birkenfeld 1999; Didier and Brunson 2004), resulting in highly varied approaches to land use and conservation (Kennedy and Brunson 2007; Lubell et al. 2013; Roche et al. 2015; Yahdjian et al. 2015). In contrast to traditional ranchers, amenity landowners often earn most of their income from interest and rent, and are drawn to rural areas as places of natural beauty rather than agricultural production (Walker and Fortmann 2003). These landowners tend to be more open to conservation-related reductions in grazing and have fewer livestock-predator tensions (Gosnell et al. 2006; Gosnell and Abrams 2011). Researchers have identified a hypothesized "drawbridge sustainability" phenomenon where rural in-migrants often actively work to prevent further in-migration, in contrast to oldtimers who generally support local economic growth (Epstein et al. 2019; Ploch 1978).

Past research sheds light on expected ecological outcomes under different landowners. Target outcomes for which "natural" and working landscapes should be managed vary significantly (Plieninger et al. 2012; Walker et al. 2003; Walker and Fortmann 2003). In other words, whether landscapes are managed in a way that is "environmentally friendly" depends on one's goals (Behnke Jr. and Scoones 1993; Huntsinger et al. 2007, 2008, 2017; Huntsinger and Oviedo 2014). Notwithstanding the popular notion that leaving landscapes alone is best for ecosystem services, biodiversity is in many cases compatible with extensive livestock operations (Dorrough et al. 2007; Grau et al. 2013; Mastrangelo and Gavin 2012). In fact, grazing cessation can at times decrease organic matter, nitrogen, and water availability, resulting in rapid shifts in plant composition and wildlife habitat in some cases (Peco et al. 2006; Plieninger et al. 2014). Debate continues around the benefits of leaving nature alone versus actively managing it for biodiversity, as seen in the rewilding and anti-rewildling movements (Holmes et al. 2020). Most often, management lies somewhere in the middle of this spectrum. Although declining agriculture and subsequent urban development can threaten biodiversity, sometimes termed the "cows vs. condos debate" (Knight et al. 1995; Walker et al. 2003), landowner turnover does not necessarily result in negative environmental outcomes (Gosnell et al. 2006).

How different landowner types produce different ecological outcomes is partly a function of rangeland management decision-making pathways. Rangeland management decisions are guided by livestock production goals, and social, economic, environmental, political and personal financial variables (Roche et al. 2015, Wilmer et al. 2018; Stuth et al. 1991) (see Fig. 1). Factors like wealth and age (Coppock and Birkenfeld 1999), property size (Lubell et al. 2013, Huntsinger and Fortmann 1990), dependence on ranch 
income, and multi-generational engagement (Didier and Brunson 2004) influence conservation activities. Management decisions are also influenced by ranchers' need for flexibility over time and space, with ranchers utilizing forage within their social networks, storing hay, and grass-banking to cope with climate, production and market related variability (Wilmer et al. 2018).

Differing ecological outcomes are also influenced by conservation program participation. In California, traditional ranchers participate in conservation programs and implement environmental improvements at a significantly higher rate than amenity landowners (Cheatum et al. 2011; Ferranto et al. 2011; Plieninger et al. 2012). Beyond government programs, neoliberal solutions to environmental protection have grown in popularity, including conservation easements and sustainability certifications. Many landowners participate in such programs, including those who prefer to avoid government-run conservation programs (Cheatum et al. 2011). At the same time, neoliberal policy tools for private land conservation have drawbacks, particularly conflict between landowners and conservationists as landowners lose control over the management agenda (Gooden and 't Sas-Rolfes 2019). Conservation easements and marketbased incentive programs shift decision-making authority to entities besides the landowner, particularly those that do not engage target communities in determining recommended management practices (Gooden and Moir 2019; Morris 2008; Serenari et al. 2016). Notwithstanding these critiques and the small percentage of land protected by conservation easements, such policies have been found to effectively prevent land cover change (Nolte et al. 2019).

This study explores recent changes in Western US rangeland ownership and implications for shifting attitudes towards both agricultural production and landscape conservation. I engage the land system and landscape sustainability sciences to answer the following motivating questions:

1. What land use transitions are taking place on Western grasslands?

2. What proximal and distal factors drive or constrain these transitions?

3. In what ways do different landowner types produce distinct ecological outcomes?

4. What policies and policy actors influence conservation outcomes in this social-ecological context?

This interdisciplinary study draws on an in-depth investigation of land use change in a cattle ranching community in California's Sierra Nevada mountain range. A landscape-scale study was selected due to the many human-environmental interactions taking place at this scale (Wu 2013). I explore land use transitions predicted by the land use transition pathways framework and the underlying political, socioeconomic and technological drivers and constraints. By integrating land cover data with social-ecological systems knowledge at the individual, household and community levels, this research highlights multifactorial influences on land use, with the end goal of improving the uptake and efficacy of public and private conservation policies targeting working lands.

\section{Methods}


This study engages a single case design (Flyvbjerg 2006) and methods from grounded theory (Charmaz 2014; Glaser and Strauss 1967) and thick description (Geertz 1973). Land system scientists use case studies to understand the socio-economic and political variables driving land use transitions (Lambin et al. 2001; Lambin and Geist 2008; Mustard et al. 2007). While lacking some of the quantitative benefits of survey design, the case study approach offers a high level of conceptual validity, given the researcher's ability to develop a detailed understanding of explanatory factors influencing the outcome, which can be lost in 'large n' studies lacking extensive exposure to any single case.

The location of this case study is Sierra Valley, California (Fig. 2), the largest alpine valley in the US (PFT 2011). Sierra Valley's landscape includes sagebrush scrub, grasslands, wetlands, and vernal pools covering approximately 49,000 ha, including the largest freshwater marsh in the Sierra Nevada (Plumas Audubon 2008). The valley provides rich wildlife habitat and is home to the greatest variety and numbers of birds in the Sierra Nevada (FRLT n.d.). Sierra Valley provides a strong case study of the socialecological processes taking place in ranching communities across California and the underlying drivers of land use change.

Land use transitions on California's rangelands deserve attention due to their vast scale, the high level of biodiversity they host, and increasing changes in land use. Livestock production is an important industry for California (USDA-NASS 2019), one of the top- 5 beef producing states in the leading country for beef production worldwide (USDA-FAS 2019). Rangelands compose half of California's land area (FRAP 2017), with almost every county grazed by cattle (UC ANR 2007). Ranching has faced strong competition in California with other land uses (Weeks et al. 1943), including most recently from high-intensity agriculture and residential or commercial development (Cameron et al. 2014).

California's grasslands are mostly privately owned (FRAP 2017) and are recognized among the world's biodiversity hotspots for native species richness (Calsbeek et al. 2003; Myers et al. 2000). The ecological values of such private lands are often greater than nature preserves and public lands due to better soils, water access, and low visitation rates (Brunson and Huntsinger 2008; Maestas et al. 2003), and also greater diversity of management practices (Schaich and Pleininger 2013; Petucco et al. 2015). On California rangelands, well-managed livestock grazing can support biodiversity, limit woody encroachment, and prevent the spread of invasive plant species (Barry 2015; Bartolome et al. 2014; Huntsinger et al. 2007; Spiegal et al. 2016). Although most ecologists agree on the negative effects of historic grazing activities, such as impacts on waterways and changing plant communities, disagreement remains around the current health of California's grazed rangelands and the role of grazing in conservation (Huntsinger and Hopkinson 1996; Starrs and Huntsinger 2012).

Sierra Valley began experiencing significant land use change beginning in the mid-19th century as European settlers claimed lands traditionally managed by the Maidu, Washoe and Paiute native tribes. As Sinnott (1976) describes in his detailed history of the area, European settlers developed agricultural industries including hay, grains, dairy and beef. Clover and timothy grass were seeded for forage, 
replacing native plants like bunchgrass, buffalo grass and wild rye. Settlers installed fencing across the valley floor and sagebrush in the higher areas of the valley was replaced with grain production. Settlers drilled artesian wells in the 1860s, which dried up following the installation of large-capacity pumps and deeper wells (Sinnott 1976). The 20th century brought railroad construction to California population centers, further fueling the Valley's economic development. Today, nearly the entire floor of Sierra Valley is covered in privately-owned ranches, with some large cattle ranches operated by absentee landowners. Cattle numbers have more than doubled in the region since 1860, according to USDA Census of Agriculture records (Haines et al. 2018).

From the early days of European settlement, Sierra Valley has been a place of not only agricultural production but also recreation and leisure. Mid-19th century visitors vacationed at the valley's still popular sulphuric hot springs, attended competitions at the local racetrack, visited nearby mountain lakes, and engaged in recreational game hunting (Sinnott 1976). Sierra Valley has recently experienced in-migration of amenity-focused residents, including commuters to nearby cities. In the 1970s, a recreational home development was built on the valley's edge, subdivided into small lots situated to provide residents with open vistas of the valley and surrounding mountains (Sinnott 1976). While the two counties in which Sierra Valley lies-Sierra and Plumas Counties-have experienced some population growth since the 1920s (based on population data from the National Historical GIS), Sierra County remains the secondleast populated county in California (Manson et al. 2020). See Fig. 3 for historical farmland trends.

\section{Data Collection}

Data collection included participant observation and semi-structured interviews with ranchers, public agency staff, local conservation groups, and a real estate agent (Stanford University IRB Protocol \#50991; see A.3 for interview protocol). Rather than sampling members of the California Cattlemen's Association-which underrepresents amenity ranchers, small-scale ranches, and landowners with distinct political values from the Association-sampling was purposed and multi-staged, informed by local community organizations and study participants. Participants were selected for variation in rancher types, property sizes, socio-economic factors, and levels of participation in conservation easement programs. Participating production ranches included traditional ranchers living full-time on the ranch and primarily occupied with agriculture, and absentee landowners with professional ranch managers running their operations. Most ranches were cow-calf operations, the first of three stages in US beef production where operations manage a herd of breeding cows whose calves are sold annually to stocker operations for additional grazing and then to large commercial feedlots (McBride and Matthews Jr. 2011). On the amenity side, some interviewees professed being independently wealthy and having strong inclinations toward environmental conservation, yet their descendants managed the land with agricultural production as a key priority. Furthest toward the amenity end of the spectrum were several operations where conservation was a higher priority than agriculture, with the land leased for grazing to others and livestock present at significantly decreased rates. In several cases, a ranch manager or employee was interviewed rather than the landowner. 
I conducted 30 semi-structured interviews in 2019 and 2020, including 24 interviews with ranchers. Interviews lasted 1-2 hours, were digitally recorded and transcribed, and were conducted in the homes of interview subjects or by phone. For those interviewed prior to the COVID-19 pandemic, I conducted followup interviews to ensure that the pandemic itself was not driving differences in perspectives surfacing in later interviews. Transcripts were analyzed using Nvivo 12, a Computer Assisted Qualitative Data Analysis Software (CAQDAS). I applied open and thematic coding using the constant comparison method developed by Glaser and Strauss (1967), in which codes were developed based on patterns perceived in initial interviews and then used to identify differences in perception between participant types. Published interview quotes were anonymized to protect the identity of interview subjects and are represented as "SV\#".

\section{Results}

Analysis of interviews and land cover data revealed several land use transitions taking place in Sierra Valley: agricultural intensification, disintensification, and residential development.

\section{Intensification}

The first documented trend was increasing alfalfa hay production over recent decades. Based on the USDA's CropScape dataset, a geo-referenced, crop-specific land cover map, Sierra Valley increased alfalfa production 67\% between 2007 and 2018 to over 4,450 ha, or almost 10\% of the valley (Boryan et al. 2011; USDA-NASS 2019) (see Fig. 4). Participants spoke to the significant increase in land converted to centerpivot irrigated alfalfa hay production since the 1990s: "We have developed a couple thousand acres [over 800 ha] of alfalfa and we put irrigation on almost all of it." (SV25)

Alfalfa hay production is perhaps the most notable form of income diversification in Sierra Valley, particularly prevalent in the more mesic regions of the valley. Hay is an important source of roughage during mountain meadows' dormant season (Holechek et al. 2003) and is also sold to dairies, feed stores, and equestrians. California is the largest producer of alfalfa in the US (Tejeda et al. 2019), with alfalfa and other hay types being the second largest crop by land area in the state (CDFA 2019; Zaccaria et al. 2017) (Fig. 5). Across the American West, alfalfa is grown on 2.8 million ha and is an important feed for livestock industries (Yost et al. 2020). Beyond alfalfa, some interviewed ranchers had also converted pasture to irrigated specialty crops such as hemp and wine grapes.

There appears to be a trend among multi-generational ranches of land use intensification over timeincluding expanding hay production-to respond to income volatility and meet the economic requirements of additional generations. As one participant explained: "There are four generations between my grandfather and my son living-contributing in their own individual ways-on the ranch ... we do cow-calf and the slightest amount of meadow hay, just enough to sustain our needs and sell a little bit for a little extra cash income for my old man's pocket." (SV29) In fact, household income is a determining factor in ranchers being able to remain on their land (Wetzel et al. 2012); as one participant pointed out, 
ranchers must generate income or their land "goes into 5 acre [2 hectare] parcels and houses." (SV25) Rangeland residents frequently draw income from sources outside of ranches, as a result decoupling their livelihoods from the land on which they live.

Production-focused ranchers highlighted the importance of diversification in making ranching financially sustainable. Ranching is a volatile and low-income business (Gentner and Tanaka 2002; Liffmann et al. 2000; Roche et al. 2015) that is mostly unprofitable when you consider the opportunity cost of investment (Andersen et al. 2002; Wetzel et al. 2012). As one producer described: "You have stellar years where you make money and you are thinking, oh my God, I have to pay taxes. And then you have year after year where you do not break even." (SV36) Participants often reported making more money from diversified businesses than from cattle, particularly for those who produced alfalfa hay. As such, all interviewed ranchers had income outside of ranching, including on-ranch businesses like alternative crops (e.g., hay, hemp, almonds, wine grapes), wool fiber, hunting clubs, vacation rentals, and wedding venues; and also off-ranch income. Most ranches were supported by full-time, off-ranch work by one spouse. As several participants noted: "Behind every successful cattle rancher is a wife who works in town." (SV20) One ranch had developed a 1.4 hectare solar array as a form of diversification, a trend documented across Western rangelands (Holecheck et al. 2015). Yet another source of diversified income identified by production ranches was conservation easements: "Hard to buy a ranch and pay for it running cattle ... we elected to put a conservation easement on that ranch to take the money and pay the ranch off." (SV14)

The need for diversified income on mountain rangelands is hardly a new phenomenon; as rangeland researchers in the 1940s explained: "Employment in a single occupation, such as mining, lumbering, or agriculture, often brings too little income for family support, whereas integration of two or more sources of income may provide a living sufficient to maintain the local populations" (Weeks et al. 1943).

With expansion of agricultural activities, overdrafting of groundwater for irrigation has become one of the greatest environmental challenges on California's rangelands (Weeks et al. 1943). Due to heightened overdrafting during a recent drought, the State of California issued the Sustainable Groundwater Management Act (SGMA) in 2014, requiring certain groundwater basins to cease groundwater overdraft. The Sierra Valley sub-basin was highlighted as a medium priority basin within SGMA due to documented groundwater declines and resulting land subsidence (Bachand et al. 2020). Ranchers expect to be affected by SGMA and have responded in different ways. Some have invested in irrigation infrastructure: "They put a moratorium on any new ag wells. I could see that coming and I did an ag well." (SV18) Others have reduced water use in anticipation of groundwater restrictions: "Now we are irrigating, but we are not trying to make hay, so we are able to pump a lot less water." (SV46)

Ranch diversification is particularly important in light of the expected impact of climate change on precipitation, forage availability, wildfire frequency, and long-term financial sustainability (Holechek et al. 2020). Yet many ranchers were skeptical about whether climate change is occuring. In response to questions about climate change, participants often cited variations in weather as a normal feature of the landscape: "I do not really believe in climate change. The climate changes every year. It is never the 
same." (SV15) Only a small number of participants highlighted the importance of adaptation given the impact of climate change on water availability, using methods like planting alternative crop species that succeed under different temperature conditions.

\section{Disintensification}

In contrast to agricultural intensification, Sierra Valley has also experienced disintensification as amenity landowners purchase property in the valley. Study participants noted the distinct cultures introduced to the community by amenity migrants, particularly the prioritization of conservation over production agriculture: "We have an influx of people in our community who are non-agriculture based ... I have had interactions with people who are completely against our way of life..." (SV29) Another participant noted: "I have noticed that the community culture has become much more of a bedroom community." (SV7)

Academic studies support this point that in-migrating amenity landowners introduce shifts in land management (Abrams and Bliss 2013). Indeed, amenity landowners in this study prioritized the environmental health of their properties over production goals. These landowners had significantly lower levels of livestock grazing on their properties, leased their land for grazing rather than managing cattle themselves, and engaged evidence-based management and scientific monitoring. Two ranches, for example, voluntarily paid a conservation non-profit to monitor wildlife populations, plant diversity, and soil health on their properties. These ranchers were less concerned than production ranches about conservation easement restrictions on grazing timing or infrastructure development. Irrigated alfalfa hay production was mostly not present on the amenity-focused properties included in this study, and those owners did not discuss the importance of building income-generating opportunities for the next generation. Notably, it is not uncommon for in-migrating landowners to purchase properties specifically for the purposes of conservation, and participants observed this taking place in Sierra Valley.

\section{Residential development}

Study participants described increasing numbers of second-home owners and commuters in Sierra Valley. Newcomers principally purchase smaller plots within one of the valley's towns rather than larger ranches, and either commute to nearby cities or use their Sierra Valley property as a retirement home or vacation home. The decision to move to the Valley is driven for some by increasing housing costs in nearby cities, which have received high levels of in-migration from higher density regions like the San Francisco Bay Area. Notwithstanding the Valley's low housing inventory and dearth of infrastructure like medical facilities and grocery stores, participants and experts explained that the COVID-19 pandemic and expansion of remote work have expedited amenity in-migration, causing a surge in the real estate market. A real estate expert described recent in-migrants to Sierra Valley as being lifestyle-oriented: "They are looking to raise families there, but not necessarily be ranchers." (SV50) Some ranchers expressed concern about in-migration leading to gentrification and increased housing prices: "There are people moving here from San Francisco ... they are kind of pushing out your average people ... for them to buy a house that is $\$ 500,000$, they would not bat an eye at that." (SV13) 
Given past concerns about urban development in Sierra Valley's future (Lage 2005), I analyzed data from the California Department of Conservation's Farmland Monitoring and Mapping Program to understand the extent to which development is occurring. These data reveal that less than $1 \%$ of Sierra Valley's land area has been converted to urban development, and under 80 ha converted in the three decades before 2018. To understand the types of properties that might be developed in the future, I obtained sales data from the Plumas Multiple Listing Service, a local real estate sales database. Looking only at sold rangeland properties over 8 ha in size, over $5 \%$ of the valley's land area (approximately 2,680 ha) was sold in the decade before 2020 . These properties included working cattle ranches, amenity ranches, meadows and timberland. Descriptions of these parcels provided by a local real estate agent highlighted their land use potential: "Can be split into 10 acre parcels"; "Used to grow hay"; "Pasture land ready to go for the entrepreneur to develop into an income producing property with a well, center pivots, and alfalfa seed."

\section{Drivers and constraints on land use}

Interviews revealed the land use transitions described above to be driven or constrained by several factors: land access, water availability, conservation policies, and intergenerational succession.

First, an important finding of this research is that increasing alfalfa production appears to be partly driven by the distal factor of decreasing land access at lower elevations. Like many livestock producers worldwide, Sierra Valley ranchers practice transhumance, utilizing rangelands in the lower-elevation foothills for winter and springtime grazing. Transhumance supports the mountain ranching economy by reducing the cost of feeding cattle in winter months: "If you have cattle and you are not sending them down below to the valley to eat grass on some rented pasture or an allotment of some sort, you will be [using] a lot of hay." (SV12) Over time, Sierra Valley ranchers have lost access to winter grazing lands due to conversion of historically-used land at lower elevations. This decrease in forage availability puts pressure on production cattle ranches to convert mountain meadows for alfalfa production. Several interviewees spoke to this:

"It is cutthroat to find winter ground because either it's going up in houses or it is getting burnt, or it is in almonds ... You could have a piece of ground tied up and the next year it is gone." (SV29)

"Last year we lost a bunch of feed in the Chico fire... We always have enough hay so that if we have to, we can stay home ... leave that barn full, just in case." (SV25)

Ranchers explained that local land access has also been reduced as grazinglands come under the management of amenity ranchers and land trusts, with some of these lands leased to ranchers but grazing levels significantly reduced. As one rancher described: "If grazing is your sole source of income, it is tough to raise a family on anything less than a thousand acres [400 ha]... you've got to find land and a lot of this land is starting to be bought up by non-producers." (SV11) At the same time, while in-migrants often reduce grazing levels on their properties, some participants hypothesized that in-migration could 
increase grazing lands access if in-migrants convey conservation easements and thus reduce land values.

Some participants described forage availability as additionally impacted by recent declines in snowpack, which some scientists have attributed to climate change (Gergel et al. 2017; Sun et al. 2019). As one participant explained: "Snowpack is our reservoir. If you get earlier melts, then you have to anticipate what will happen in August when you run out of grass." (SV11)

Declining forage availability is also the result of reductions in grazing on public lands grazing allotments. Both ranchers and experts described grazing access as having decreased over time due to environmental restrictions. Notably, rangeland research has found that reductions in grazing on public lands increases intensity of agricultural activities on private lands, particularly increased grazing and conversion to hay production (Runge et al. 2019). Both ranchers and some Forest Service staff expressed strong interest in expanding the use of public lands for grazing and streamlining the process for landowners. One participant spoke to the regulatory and financial burden of accessing public lands grazing allotments:

"A Forest Service allotment was attached to this ranch. So three or four years ago, I spoke to one of the [Range Conservationist] guys at the Forest Service. And he says, oh yeah, it has not been active for 30 years. And I said, okay, great, what do I need to do to get that going? And he says, well about $\$ 60,000$ to start with for an environmental study and about four or five years from now, maybe we can do it, if everything goes well." (SV46)

A second factor influencing land use conversion in Sierra Valley is increasing water availability. Increases in irrigation have become possible because of both significant regional development of water infrastructure and modern irrigation technologies. A perennial species, alfalfa requires a high level of water input (Zaccaria et al. 2017). Historic dam construction transformed land uses in Sierra Valley from dryland farming to irrigated pasture, with drilling of agricultural wells escalating in the mid-20th century as larger cattle operations moved to the valley and neighbors raced to further augment water access (Sinnott 1976). With more water now available and improvements in irrigation technology, meadows were plowed and irrigated to increase the efficiency of hay production. Both production-focused and amenityfocused ranches expressed some concern about the conversion of native grassland to hay production. As one amenity-focused landowner shared about a nearby property: "He plowed the whole thing and planted hay ... of course he had one good crop ... since then it's just basically weeds and mostly cheatgrass. And then it got turned over to a horse sanctuary. So now you have a dust bowl." (SV45) One expert noted the fine balance between resource use and conservation: "It is common knowledge that you can overtax the groundwater and it will affect wetlands. But at the same time, folks have to make a living." (SV17) A production rancher also spoke to this tension: "Since the meadows did not produce much, they got plowed up, much to my dismay. I love the meadows. Since we had to make a living, that was the thing to do. But what has been plowed up is gone." (SV26)

While irrigation technology developments allow for agricultural intensification, water and energy policies can have the opposite effect. Because of its high dependence on water, alfalfa production is significantly 
impacted by changing water and power costs: "A lot of our water comes from irrigation wells ... The power bill is exorbitant. It just seems to get higher every year." (SV14) Notwithstanding increasing irrigation costs, most participants did not report implementing water usage reductions. Some participants expressed concerns about future restrictions on water use from state groundwater policies limiting agricultural communities' ability to produce food:

"Water is kind of liquid gold to us out here... to me, there is a double standard. Just take [Las] Vegas, for instance. How many hotels are out there that consume water? Showers, golf courses, swimming pools ... But they look at how the farmers take too much water. If they really stop us from farming and utilizing so much of this water, where's the food going to come from?" (SV42)

Participants pointed to water as one of the most significant factors influencing the future of the valley and possible land uses, given that irrigation enables alfalfa production and thus diversified income. Looking ahead, continued fluctuations in the alfalfa market and state restrictions on groundwater pumping may result in ranch operations investing in alternative crops to meet the financial needs of the next generation.

Thirdly, land use transitions in Sierra Valley are influenced by conservation policy, including policies focused on preventing urban development like County General Plans, state farmland protection policy (e.g., California's Williamson Act), and conservation easements. To prevent urban development, particularly when the next generation is not interested in ranching, a number of ranches in Sierra Valley have conveyed easements to conservation organizations. Both amenity and production ranches with easements reported a high level of satisfaction: "We felt like it was a pretty easy process ... we cannot grow a lot of stuff ... so our easement works out really well for us." (SV20).

While conservation policies can prevent intensification and conversion, they can also be problematic for ranches. Sierra Valley ranchers shared frustrations that site-specific or local factors were not often incorporated into state or national rangeland policies. This sentiment supports the recommendation that regulators work more closely with natural resource managers in policy development (Ostrom and Cox, 2010). In particular, the requirements necessary for producers to receive NRCS cost-sharing grants for conservation work are frequently a barrier to participation. For example, NRCS conservation program participation could require an archaeologist and biologist evaluate ranches for potential historical significance and endangered species. Many ranchers are wary of such requirements, as one expert described: "People still get hung up about not wanting to participate with NRCS because they still just do not know what will be done to them." (SV6)

In light of the importance of diversification to ranch sustainability, production ranches reported concerns about conservation policies or programs limiting their ability to run economically viable operations. Interviewed ranchers were particularly concerned about grazing limitations-whether relevant to grazing allotments or conservation easements. Seasonal grazing restrictions in conservation easements, often inserted for the purposes of protecting nesting birds, can cause ranchers to lose a significant portion of the summer grazing season (generally mid-May through mid-July). As participants explained: 
"These newer easements are a lot more strict than the first ones that basically just kept open spaces open. Now they have really strict grazing standards, and it reduces the number of cattle that can run and often you are grazing at a poor time for the cattle." (SV47)

"It always seems to end up being July 15th when cattle can start grazing. Well, that is two months into your typical grazing season here." (SV2O)

Production ranchers described grazing season delays required by some recently negotiated easements to be an impossible commitment for producers. This concern reflects the Sierra Westside cattle production cycle, with green forage waning in June and replaced by dry forage with inadequate protein content by late summer (Fig. 6).

Figure 6 Conservation easements that limit spring and early summer grazing can be challenging for ranchers, as the most nutritious forage is available in May and June. Lines represent herd demand for protein content and bars represent protein content on mountain meadows. Source: University of California Agriculture and Natural Resources (George et al. 2001)

Beyond concerns about grazing restrictions, some traditional ranchers also feared that conservation easements that limited future building construction may stymie the ability of future generations to diversify, innovate and develop new agricultural businesses. Ranchers were concerned that restrictions on grazing or hunting could also limit such diversification. As one producer noted: "The problem with easements, there are a lot of hidden restrictions to them ... It is really tricky for keeping the ranch in agriculture." (SV10) Ranchers and experts participating in this study called for less of a top-down approach to land use governance and more flexibility: "The issue you deal with is a lot of the regulations are written by people who have no actual knowledge of what it takes to run an economically viable operation." (SV11)

Given the sentiments described above, the long-term potential for neoliberal conservation programs like conservation easements to be scaled and successfully prevent land use change will likely be constrained by how well these concerns are addressed. While some organizations have worked to implement easements with fewer restrictions (e.g., The California Rangeland Trust was created by ranchers for this purpose), their implementation has been limited by lack of conservation funding available for less stringent easements.

Finally, while some ranches intensify land use to support additional generations, land use can also be impacted by loss of intergenerational succession. As one participant explained: "[The next generation] makes too much money in other jobs .. they are all interested in it, but they just want to do it when they feel like having fun." (SV15) In many cases, the younger generation does not have the financial stability to support the family business once the ranch is passed down. When members of the next generation are no longer interested in ranching, ranches are at greater risk for subdivision and sale: "There were six of us 
kids and all of us got married and all of us have kids. And then our kids are having kids... How do you instill the value of this land compared to money? It is hard for me to see that the land is not going to just be easier to sell than to work at it and to continue to preserve this family farm for future generations." (SV42)

\section{Heterogeneity in landscape management}

Sierra Valley landowners participating in this study held many common values for land management. Both amenity and production ranchers defined conservation as having to do with sustainable use of the landscape: "Conservation is a love of the land and trying to maintain and better it ... We are stewards of land." (SV29) Landowners reported implementing a variety of conservation activities, including managing for native plants, pollinators and wildlife and protecting riparian areas. As other researchers have found both in Sierra Valley and other California ranching communities (Aoyama and Huntsinger, 2019; Lage 2005), both types of ranchers explained that rangelands need to be actively managed by humans to support ecosystem services. Without grazing, many believed that rangelands would turn into a "jungle" of invasive species and be poor habitat for wildlife: "If there were no cows here, this place would just be a big, wild mess. We have noticed since we have been grazing the cows out in the back, there is a lot of grass growing where it was not growing before. Keep the weeds down." (SV15) Ranchers emphasized the role of grazing in supporting the health of the landscape, a concept widely supported by rangeland experts (Barry 2015; Bartolome et al. 2014; Huntsinger and Hopkinson 1996). In fact, some academics have hypothesized that increases in amenity landownership could result in reduced ecosystem health due to lower levels of active management (Plieninger et al. 2012). Participants also highlighted the importance of grazing for preventing catastrophic wildfires that diminish habitat: "Forest fires go through and it looks like the surface of the moon when they are done. You know what is better? Having some cattle and some loggers in there trying to manage it." (SV46)

Ranchers' varying focus on production agriculture appears to result in distinct types of habitat. Agricultural activities can provide valuable habitat to species (Huntsinger et al. 2017; Lomba et al. 2020). For example, migrating birds are drawn to water on irrigated lands in the wet parts of the valley, and pronghorn have returned to Sierra Valley in numbers not seen in a generation, largely because of the irrigated alfalfa fields of production ranches. Mule deer, pronghorn, and migrating birds are generally accepted by production ranchers as a natural part of the landscape, if competitors for forage.

Participants explained that production agriculture can support wildlife in Sierra Valley by increasing water and feed availability:

"Irrigating those meadows, which had gone unirrigated for so long, we ... it changed the vegetation and brought the meadows back to life. We used to see maybe a hundred geese and now we see a thousand. Right here, there were no deer ... Now they are back here." (SV18)

"The wildlife is a byproduct of this ranch. We basically have a huge bird sanctuary here ... There are places in the valley that people really like to go bird watch, but they would probably do a backflip if they saw where all the birds really are." (SV47) 
At the same time, some agricultural activities negatively impact wildlife, habitat, and groundwater, as when rangelands are converted for crop production. Production ranchers reported removing beaver, muskrat, coyote, bear, and elk because of their negative impacts on agriculture. For example, elk can cause livestock stress due to their aggressive interactions with cattle: "Elk will herd those cows into a harem. Two years ago, an elk drove a calf away and killed it with his horns." (SV18) Ranchers frequently remove beavers and muskrats because of their impact on water systems: "I had to tear a beaver dam out yesterday because he has blocked it all up." (SV13) Wolves, documented in the area since the mid-19th century (Sinnott, 1976), can impact ranches directly through predation of livestock and guardian animals, as well as indirect impacts on livestock weight gain from heightened stress. As one participant explained, "Compensation is a tricky thing, because the real damage a wolf does is not the kill it makes, but the general health of the whole herd. Stress of rebreeding, weight gain ... and on the ranchers. I do not think people understand what it is like fearing that something is out there going to attack your herd." (SV25) Some amenity ranchers who personally manage livestock also shared concerns about such predator species returning to Sierra Valley: "There is that side of me where I understand the importance of wildlife and corridors and then there is that other side of me where I am a rancher now ... I want this impenetrable, fenced area where I know that our animals are okay... It is an interesting conundrum for me." (SV11)

\section{Discussion}

The land use transitions identified in this study can be mapped onto broader trends predicted by the transition pathways framework (Fig. 7). Depending on the buyer and whether a property has conveyed a conservation easement, loss of intergenerational succession and ranch sales can result in intensification, disintensification, or residential and commercial development.

Figure 7 The land use transition pathways framework adapted from Foley et al. (2005), DeFries et al. (2004), Mustard et al. (2007). Several factors have been added to the framework in the context of Sierra Valley, including amenity landownership, solar development, extensive grazing (an ongoing type of less intensive frontier land use), and native management. Sierra Valley has a long history of use and management by Native Americans; archeological evidence supports native tribes residing in the area for at least 5,000 years (Waechter and Ekness Norton, n.d.) and being in California for at least 19,000 years (Klein 1995)

Proximal influences on land use change often receive more attention than the distal or underlying factors, yet this case study has highlighted a multitude of factors at proximal and distal scales influencing land use change in Sierra Valley (Fig. 8). At a local level, proximal factors like zoning policies and conservation easements can constrain development. Other local factors can drive land use intensification, such as dam development, water competition, and demand for irrigated crops. Intensification is also driven by distal factors like forage losses at lower elevations, and can be constrained by state policies (e.g., groundwater limitations) and changes in land ownership. 
Figure 8 Proximal factors are shown in bold, and distal factors in non-bold font. This figure builds on the transition pathways framework (Foley et al. 2005; DeFries et al. 2004; Mustard et al. 2007) and socialecological systems frameworks developed by Ostrom and Cox (2010) and Charnley et al. (2018). Photo credits: Judy Gallagher@flickr, freepik@flaticon.com

\section{Implications of land ownership change}

Changes in land ownership broaden the possibility of changes in land use; although such transitions are not necessarily equivalent to changes in land cover, they can impact the provisioning of ecosystem services (Lambin and Meyfroidt 2010). The impacts of landownership on ecological outcomes can be evaluated with the land sharing / land sparing framework. On one end of the spectrum, land sharing indicates agriculture that is less intensive and amenable to ecosystem services like biodiversity. Policies focused on this approach, often called High Nature Value farming, support rural communities in partnering with nature to produce ecosystem services (Feniuk et al. 2019; Huntsinger and Oviedo 2014; Lomba et al. 2020) and support heterogeneity (Fischer et al. 2008). In contrast, land sparing implies that agricultural intensity is increased in some areas so that other land can be left aside where nature can thrive (Grau et al. 2013). While irrigated crops can support biodiversity in some cases (Yost et al. 2020), land sparing is believed to be critical for species particularly incompatible with human activities, such as large predators.

As in other ranching communities, Sierra Valley landowners' mental models for their properties most often align with the concept of land sharing, with agriculture amenable to provisioning ecosystem services. In contrast, conservationists have traditionally focused on creating nature preserves under the land sparing and "rewilding" models, but in recent decades have shifted toward a land sharing approach using conservation easements and wildlife-friendly agriculture programs. In the case of Sierra Valley, High Nature Value farming has provided rich habitat for species like pronghorn, deer and migratory birds, while increasing amenity ownership in the valley may expand habitat for species less tolerated by production ranches.

Given the distinct habitat provided by different ranch types, experts suggest that agricultural policies integrate both approaches by supporting heterogeneity on agricultural lands, including interweaving large areas of native ecosystems into working lands (Fischer et al. 2008). Thus a diversity of grazing management regimes-as seen in Sierra Valley's mosaic of land ownership-may be a promising strategy for long-term landscape conservation and biodiversity (Fuhlendorf and Engle 2001; Grau et al. 2013; Peco et al. 2006). In other words, production agriculture supports some wildlife through increasing water and feed availability, while disintensified ranches and nature preserves provide valuable habitat to species that compete with or are detrimental to production agriculture. Well-managed cattle grazing will continue to offer important ecological benefits, including supporting biodiversity by preventing invasion of nonnative grasses, shrub encroachment, and fragmentation. As human population growth into fire-prone areas makes traditional fire management regimes more difficult to implement, livestock grazing could aid in reducing vegetative fuel loads and preventing woody encroachment. At the same time, continued

Page $17 / 37$ 
preservation of old-growth and restored grasslands is needed to support long-term biodiversity, particularly for native perennial grasses and forbs (Nerlekar and Veldman 2020).

\section{Opportunities for upscaling grasslands conservation}

Conservation policies could be upscaled across Western working lands if financial and policy issues are resolved. The financial burden that conservation policies often place on producers can be significant, such as when allotment management costs are placed on producers rather than the managing agency. Given some landowners' economic dependence on the agricultural productivity of their ranches, conservation program participation is limited by perceived anti-agricultural framing (Cross et al. 2011; Kabii and Horwitz 2006; Merenlender et al. 2004). If conservation easements are structured in a way that is amenable to the production needs of traditional agricultural operations, and if adequate funding is secured from public and private sources, conservation policies could play an expanded role in preventing grassland conversion.

Upscaling landscape sustainability solutions requires alignment across policy actors operating at different scales within the hybrid governance model (Lambin et al. 2020). Conservationists interested in preventing grasslands conversion should consider the underlying drivers operating at both proximal and distal scales. Pressure on mountain meadows could be relieved by state policies supporting transhumance and grazing lands access-both on public and private lands-for cow-calf operations. From a science education perspective, the climate change skepticism documented in this study highlights the need to engage rural landowners on climate science and opportunities for adaptation, to mitigate the expected impacts of climate change on cattle production. Conservative environmental groups such as the American Conservation Coalition that frame environmental goals within market-based, limited government ideologies could be utilized in this outreach to increase traction. From a societal perspective, diets shifting toward nuts, grains and wine can have unintended consequences as ecologically rich, grazed grasslands are converted to intensive crop production; the role of policy in mitigating these impacts should be further explored.

Related to water use, while groundwater overdrafting is unsustainable both from an environmental and agricultural viability perspective, it occurs because ranches operate at low margins with high income variability. Diversification of ranch income through innovative business models or payments for ecosystem services could bolster ranch income and should be supported by policymakers, private sector initiatives, and corporations.

Finally, in light of the trends of rural gentrification and expansion of remote work, there is a growing opportunity to engage amenity landowners individually and through collaborative initiatives, both public and private. Such engagement could focus on managing for specific conservation outcomes (e.g., rebuilding native ecosystems, preventing the spread of invasive plants, protecting old-growth and restored grasslands) and supporting the agricultural viability of landscapes by providing grazing access to production-focused ranchers. Future research is needed to document the particular plant and animal species supported by various land management activities; while amenity landowners utilize non- 
traditional capital resources to enable adaptive management, science-based decision-making by ranchers could be supported through private initiatives that provide scientific monitoring at low or no cost.

\section{Study limitations}

Case studies present several weaknesses, including uncertainty around the generalizability of identified relationships to other geographies and the difficulty of conducting meta-analyses on studies of this nature, as interview data must be kept confidential (Rindfuss et al. 2007). This study undersampled amenity and absentee landowners and is likely biased towards more actively engaged members of the community. I endeavored to address this by contacting new landowners identified in real estate sales data; however, this method was unsuccessful in securing interviews. Undersampling of absentee landowners in rangelands research is particularly concerning given recent rangeland ownership trends. Finally, study conclusions may be limited by sample size; yet these interviews covered over half of Sierra Valley and so captured the perspectives of a significant portion of landowners in the case study site. The interview campaign was discontinued when I reached an interview saturation point-with similar responses generated from each additional interview-signaling an adequate sample size for the purposes of this analysis (Glaser and Strauss 1967).

\section{Conclusion}

This study explored land use transitions on private grasslands in the Western US, underlying proximal and distal drivers, the implications of landownership change for ecological outcomes, and policies influencing land use change in ranching communities today. Through an in-depth, mixed methods case study of a mountain ranching community, I identified several land use trends: intensification for alfalfa production, residential and solar development, and disintensification resulting from amenity migration. Key influences on land use change included decreased access to forage, changes in water availability, conservation policies, and intergenerational succession. Engaging the land sharing / land sparing framework, I highlighted similarities in perspectives on land management between traditional and amenity ranchers and areas where these mental models diverge between landowner types, creating distinct ecological outcomes. Based on these findings, several factors appear critical to protecting the ecosystem services of privately owned grasslands: grazinglands access, income diversification opportunities, regulations that ensure groundwater recharge, agriculture-friendly conservation easements, and local and state policies supporting transitions to amenity landownership rather than low-density development.

Rangelands are managed by humans for varied values and outcomes, whether agricultural production, scenic and cultural value, energy production, or habitat conservation. Public and private conservation programs can be designed with these goals and values in mind, and effective implementation is dependent on the mental models and decision processes of individual land managers. Future research should explore the efficacy of specific conservation policies and programs in shaping the management decisions of both production and amenity-focused range landowners, and the best process for community-engaged conservation of privately owned landscapes. 


\section{Declarations}

Research methods were approved by the Stanford University IRB (Protocol \#50991).

\section{Conflict of Interest}

The author declares to have no conflict of interest.

\section{Acknowledgements}

This work was supported by a McGee Grant from the Stanford School of Earth, Energy, and Environmental Sciences and a summer research grant from the Emmett Interdisciplinary Program in Environment and Resources (EIPER) at Stanford University. My sincere thanks go to the ranchers and experts who participated in this study for generously sharing their time and personal perspectives. I am grateful for the thoughtful guidance of this project by Dr. Eric Lambin at Stanford University and Dr. Lynn Huntsinger at University of California Berkeley, as well as Dr. Bruce Cain and Dr. Gabrielle Wong-Parodi at Stanford University for their advising during the research process.

\section{References}

Abrams J, Bliss JC (2013) Amenity landownership, land use change, and the re-creation of "working landscapes". Soc Nat Resour 26(7):845-859. https://doi.org/10.1080/08941920.2012.719587

Andersen M, Blank S, LaMendola T, Sexton R (2002) California's cattle and beef industry at the crossroads. Calif Agr 56(5):152-156. https://doi.org/10.3733/ca.v056n05p152

Aoyama L, Huntsinger L (2019) Are landowners, managers, and range management academics on the same page about. conservation? Rangelands 41(1):61-69. https://doi.org/10.1016/J.RALA.2018.10.001

Asner GP, Elmore AJ, Olander LP, Martin RE, Harris AT (2004) Grazing systems, ecosystem responses, and global change. Annu Rev Env Resour 29:261-299.

https://doi.org/10.1146/annurev.energy.29.062403.102142

Bachand PAM, Burt KS, Carlton S, Bachand SM (2020) Groundwater relationships to pumping, precipitation and geology in high-elevation basin. Sierra Valley, CA. Bachand \& Associates, http://aquaticcommons.org/27004

Barry S (2015) The benefits of livestock grazing California's annual grasslands. University of California Division of Agriculture and Natural Resources. Publication No. 8517. Oakland, CA, U.S.A. https://anrcatalog.ucanr.edu/pdf/8517.pdf

Bartolome JW, Allen-Diaz BH, Barry S, Ford LD, Hammond M, Hopkinson P, Ratcliff F, Spiegal S, White MD (2014) Grazing for biodiversity in Californian Mediterranean grasslands. Rangelands 36(5):36-43. 
Behnke RH Jr, Scoones I (1993) Rethinking range ecology: implications for rangeland management in Africa. In: Behnke RH Jr., Scoones I, Kerven C (eds) Rangeland Ecology at Disequilibrium: New Models of Natural Variability and Pastoral Adaptation in African Savannas. Overseas Development Institute

[dataset] Boryan C, Yang Z, Mueller R, Craig M (2011) Monitoring US agriculture: The US Department of Agriculture, National Agricultural Statistics Service, Cropland Data Layer Program. Geocarto International 26(5):341-358. https://doi.org/10.1080/10106049.2011.562309

Bourque K, Schiller A, Loyola Angosto C, McPhail L, Bagnasco W, Ayres A, Larsen A (2019) Balancing agricultural production, groundwater management, and biodiversity goals: A multi-benefit optimization model of agriculture in Kern County, California. Sci Total Environ 670:865-875. https://doi.org/10.1016/j.scitotenv.2019.03.197

Brain RG, Hostetler ME, Irani TA (2014) Why do cattle ranchers participate in conservation easement agreements? Key motivators in decision making. Agroecol Sustain Food Syst 38:299-316. https://doi.org/10.1080/21683565.2013.819479

Brummel RF, Nelson KC (2014) Does multifunctionality matter to US farmers? Farmer motivations and conceptions of multifunctionality in dairy systems. J Environ Manage 146:451-462. https://doi.org/10.1016/j.jenvman.2014.07.034

Brunson MW, Huntsinger L (2008) Synthesis Paper: Ranching as a conservation strategy: can old ranchers save the new West? Rangel Ecol Manag 61(2):137-147

Bürgi M, Hersperger AM, Schneeberger N (2004) Driving forces of landscape change-Current and new directions. Landscape Ecol 19(8):857-868. https://doi.org/10.1007/s10980-004-0245-8

[FRAP] CALFIRE Fire and Resource Assessment Program (2017) California's Forests and Rangelands: 2017 Assessment, 63-83. California Department of Forestry and Fire Protection. http://frap.fire.ca.gov/assessment2017/index

Calsbeek R, Thompson JN, Richardson JE (2003) Patterns of molecular evolution and diversification in a biodiversity hotspot: the California Floristic Province. Mol Ecol 12:1021-1029.

https://doi.org/10.1046/j.1365-294X.2003.01794.x

Cameron DR, Marty J, Holland RF (2014) Whither the rangeland?: Protection and conversion in California's rangeland ecosystems. PLoS ONE 9(8):1-12. https://doi.org/10.1371/journal.pone.0103468

CDFA (2019) 2018-2019 California Agricultural Statistics Review. https://www.cdfa.ca.gov/statistics/PDFs/2018-2019AgReportnass.pdf

Charmaz K (2014) Constructing Grounded Theory, 2nd edn. Sage Publications, London 
Charnley S, Gosnell H, Wendel KL, Rowland MM, Wisdom MJ (2018) Cattle grazing and fish recovery on US federal lands: Can social-ecological systems science help? Front Ecol Environ 16(S1):S11-S22. https://doi.org/10.1002/fee.1751

Cheatum M, Casey F, Alvarez P, Parkhurst B (2011) Payments for ecosystem services: A California rancher perspective. Conservation Economics and Finance Program White Paper.

https://carangeland.org/images/payments_for_ecosystem_services_a_california_rancher_perspective.pdf

Chen R, Ye C, Cai Y, Xing X, Chen Q (2014) The impact of rural out-migration on land use transition in China: Past, present and trend. Land Use Policy 40:101-110.

https://doi.org/10.1016/j.landusepol.2013.10.003

Cook J, Oreskes N, Doran PT, Anderegg WRL, Verheggen B, Maibach EW, Carlton JS, Lewandowsky S, Skuce AG, Green SA, Nuccitelli D, Jacobs P, Richardson M, Winkler B, Painting R, Rice K (2016) Consensus on consensus: A synthesis of consensus estimates on human-caused global warming. Environ Res Lett 11(4):048002. https://doi.org/10.1088/1748-9326/11/4/048002

Coppock DL, Birkenfeld AH (1999) Use of livestock and range management practices in Utah. J Range Manage 52(1):7. https://doi.org/10.2307/4003486

Cramer VA, Hobbs RJ, Standish RJ (2008) What's new about old fields? Land abandonment and ecosystem assembly. Trends Ecol Evol 23:104-112. https://doi.org/10.1016/j.tree.2007.10.005

Cross JE, Keske CM, Lacy MG, Hoag DLK, Bastian CT (2011) Adoption of conservation easements among agricultural landowners in Colorado and Wyoming: The role of economic dependence and sense of place. Landsc Urban Plan 101:75-83. https://doi.org/10.1016/j.landurbplan.2011.01.005

DeFries R, Eshleman KN (2004) Land-use change and hydrologic processes: A major focus for the future. Hydrol Process 18(11):2183-2186. https://doi.org/10.1002/hyp.5584

Denzau AT, North DC (1994) Shared Mental Models: Ideologies and Institutions. Kyklos 47:3-31. https://doi.org/10.1111/j.1467-6435.1994.tb02246.x

Didier EA, Brunson MW (2004) Adoption of range management innovations by Utah Ranchers. J Range Manage 57(4):330. https://doi.org/10.2307/4003855

Dorrough J, Moll J, Crosthwaite J (2007) Can intensification of temperate Australian livestock production systems save land for native biodiversity? Agric Ecosyst Environ 121(3):222-232.

https://doi.org/10.1016/j.agee.2006.12.012

Epstein K, Haggerty JH, Gosnell H (2019) Super-rich landowners in social-ecological systems: Opportunities in affective political ecology and life course perspectives. Geoforum 105:206-209. https://doi.org/10.1016/j.geoforum.2019.05.007 
Farley KA, Walsh KC, Levine AS (2017) Opportunities and obstacles for rangeland conservation in San Diego county, California, USA. Ecol Soc 22(1). https://doi.org/10.5751/ES-09077-220138

[FRLT] Feather River Land Trust. (n.d.) Sierra Valley Preserve. https://www.frlt.org/conserve-land/successstories/sierra-valley-preserve

Feniuk C, Balmford A, Green RE (2019) Land sparing to make space for species dependent on natural habitats and high nature value farmland. Proc. Royal Soc. P Roy Soc B-Biol Sci 286(1909), 20191483. https://doi.org/10.1098/rspb.2019.1483

Ferranto S, Huntsinger L, Getz C, Nakamura G, Stewart W, Drill S, Valachovic Y, DeLasaux M, Kelly M (2011) Forest and rangeland owners value land for natural amenities and as financial investment. Calif Agr 65(4):184-191. https://doi.org/10.3733/ca.v065n04p184

Ferranto S, Huntsinger L, Kelly M (2014) Sustaining ecosystem services from private lands in California: The role of the landowner. Rangelands 36(5):44-51. https://doi.org/10.2111/RANGELANDS-D-1400023.1

Fischer J, Brosi B, Daily GC, Ehrlich PR, Goldman R, Goldstein J, Lindenmayer DB, Manning AD, Mooney HA, Pejchar L, Ranganathan J, Tallis H (2008) Should agricultural policies encourage land sparing or wildlife-friendly farming? Front Ecol Environ 6(7):380-385. https://doi.org/10.1890/070019

Flyvbjerg B (2006) Five misunderstandings about case study research. Qual Inq 12(2):219-245

Foley JA, DeFries R, Asner GP, Barford C, Bonan G, Carpenter SR (2005) Global consequences of land use. Science 309(5734):570-574

Freedgood J, Hunter M, Demsey J, Sorenson A (2020) Farms under threat: the state of America's farmland. American Farmland Trust, Northampton. https://farmland.org/project/farms-under-threat

Fuhlendorf SD, Engle DM (2001) Restoring heterogeneity on rangelands: ecosystem management based on evolutionary grazing patterns. Bioscience 51(8):625. https://doi.org/10.1641/00063568(2001)051[0625:RHOREM]2.0.CO;2

Geertz C (1973) Thick description: Toward an interpretive theory of culture. In: The Interpretive Theory of Culture. Basic Books, New York, pp 3-30

Geist HJ, Lambin EF (2002) Proximate causes and underlying driving forces of tropical deforestation. Bioscience 52(2):143. https://doi.org/10.1641/0006-3568(2002)052[0143:PCAUDF]2.0.CO;2

Gentner BJ, Tanaka JA (2002) Classifying federal public land grazing permittees. J Range Manage 55(1):2-11. https://doi.org/10.2307/4003256 
George M, Glenn N, Dunbar J (2001) Balancing beef cow nutrient requirements and season forage quality on annual rangeland. University of California Division of Agriculture and Natural Resources. Publication No. 8021. Oakland, CA, U.S.A

Gergel DR, Nijssen B, Abatzoglou JT, Lettenmaier DP, Stumbaugh MR (2017) Effects of climate change on snowpack and fire potential in the western USA. Clim Change 141(2):287-299.

https://doi.org/10.1007/s10584-017-1899-y

Glaser BG, Strauss AL (1967) The discovery of grounded theory: Strategies for qualitative research. Aldine Publishing Co., Chicago

Gooden J, Moir FC (2019) Consensus, clusters, and trade-offs in wildlife-friendly ranching: An advance analysis of stakeholder goals in northern Mexico. Biol Conserv 236:443-451. https://doi.org/10.1016/j.biocon.2019.06.004

Gooden J, 't Sas-Rolfes M (2019) A review of critical perspectives on private land conservation in academic literature. Ambio 49:1019-1034. https://doi.org/10.1007/s13280-019-01258-y

Gosnell H, Abrams J (2011) Amenity migration: Diverse conceptualizations of drivers, socioeconomic dimensions, and emerging challenges. GeoJournal 76(4):303-322. https://doi.org/10.1007/s10708-0099295-4

Gosnell H, Haggerty JH, Travis WR (2006) Ranchland ownership change in the Greater Yellowstone ecosystem, 1990-2001: Implications for conservation. Soc Natur Resour 19(8):743-758. https://doi.org/10.1080/08941920600801181

Gosnell H, Travis W. R. (2005) Ranchland ownership dynamics in the Rocky Mountain west. Rangeland Ecol and Manag 58(2): 191-198. https://doi.org/10.2111/1551-5028(2005)58<191:RODITR>2.0.C0;2

Grau R, Kuemmerle T, Macchi L (2013) Beyond 'land sparing versus land sharing': Environmental heterogeneity, globalization and the balance between agricultural production and nature conservation. Curr Opin Environ Sustain 5(5):477-483. https://doi.org/10.1016/j.cosust.2013.06.001

Haggerty JH, Auger M, Epstein K (2018) Ranching sustainability in the Northern Great Plains: An appraisal of local Perspectives. Rangelands 40(3):83-91. https://doi.org/10.1016/j.rala.2018.03.005

[dataset] Haines M, Fishback P, Rhode P (2018) United States Agriculture Data, 1840-2012. Interuniversity Consortium for Political and Social Research. https://doiorg.stanford.idm.oclc.org/10.3886/ICPSR35206.v4

Holecheck JL, Sawalhah MN, Cibils AF (2015) Renewable energy, energy conservation, and US rangelands. Rangelands 37(6). https://doi.org/10.1016/j.rala.2015.10.003 
Holechek JL, Geli HME, Cibils AF, Sawalhah MN (2020) Climate change, rangelands, and sustainability of ranching in the Western United States. Sustainability 12(12):4942. https://doi.org/10.3390/su12124942

Holechek JL, Pieper RD, Herbel CH (2003) Range management: principles and practices, 5th edn. Prentice Hall, Englewood Cliffs

Holmes G, Marriott K, Briggs C, Wynne-Jones S (2020) What is rewilding, how should it be done, and why? A Q-method study of the views held by European rewilding advocates. Conserv Soc 18(2):77.

https://doi.org/10.4103/cs.cs_19_14

Huntsinger L, Bartolome JW, D’Antonio CM (2007) Grazing management on California's Mediterranean grasslands. In: Stromberg M (ed) California Grasslands: Ecology and Management. University of California Press, Berkeley, pp 232-253

Huntsinger L, Fortmann LP (1990) California's privately owned oak woodlands: Owners, use, and management. J Range Manag 43:147-152. https://doi.org/10.2307/3899034

Huntsinger L, Hopkinson P (1996) Viewpoint: Sustaining rangeland landscapes: A social and ecological process. J Range Manage 49(2):167-173. https://doi.org/10.2307/4002689

Huntsinger L, Hruska TV, Oviedo JL, Shapero MWK, Nader GA, Ingram RS, Beissinger SR (2017) Save water or save wildlife? Water use and conservation in the central Sierran foothill oak woodlands of California, USA. Ecol Soc 22(2):12. https://doi.org/10.5751/ES-09217-220212

Huntsinger L, Johnson M, Stafford M, Fried J (2008) A resurvey of oak woodland landowners: 1985, 1992, and 2004. In: Merenlender A, McCreary D, Purcell KL (tech eds) Proceedings of the Sixth California Oak Symposium: Today's Challenges, Tomorrow's Opportunities. Gen. Tech. Rep. PSW-GTR-217. Albany, California: USDA Forest Service, Pacific Southwest Research Station

Huntsinger L, Oviedo JL (2014) Ecosystem services are social-ecological services in a traditional pastoral system: The case of California's Mediterranean rangelands. Ecol Soc 19(1):8. https://doi.org/10.5751/es-06143-190108

Hurst KF, Ramsdell CP, Sorice MG (2017) A life course approach to understanding social drivers of rangeland conversion. Ecol Soc 22(1). https://doi.org/10.5751/ES-08990-220119

IPCC (2013) Climate Change 2013: The Physical Science Basis. Contribution of Working Group I to the Fifth Assessment Report of the Intergovernmental Panel on Climate Change. Stocker TF, Qin D, Plattner GK, Tignor M, Allen SK, Boschung J, Nauels A, Xia Y, Bex V, Midgley PM (eds). Cambridge University Press, New York

Jackson-Smith DB (2003) Transforming rural America: The challenges of land use change in the twentyfirst century. In: Brown DL, Swanson LE (eds) Challenges for rural America in the twenty-first century. The Pennsylvania State University Press, University Park, pp 305-316 
Jones NA, Ross H, Lynam T, Perez P, Leitch A (2011) Mental models: An interdisciplinary synthesis of theory and methods. Ecol Soc 16. https://www.jstor.org/stable/26268859

Kabii T, Horwitz P (2006) A review of landholder motivations and determinants for participation in conservation covenanting programmes. Environ Conserv 33:11-20.

https://doi.org/10.1017/S0376892906002761

Kahle D, Wickham H (2013) ggmap: Spatial visualization with ggplot2. The R Journal 5:144-161. http://journal.r-project.org/archive/2013-1/kahle-wickham.pdf

Kennedy CA, Brunson MW (2007) Creating a culture of innovation in ranching. Rangelands 29(3):35-40. https://doi.org/10.2111/1551-501x(2007)29[35:cacoii]2.0.co;2

Klein BT (1995) Evidence of human occupation of California dates from at least 19,000 years ago. In: Reference Encyclopedia of the American Indian. Todd Publications, West Nyack, New York

Knight RL, Wallace GN, Riebsame WE (1995) Ranching the view: Subdivisions versus agriculture. Conserv Biol 9:459-461. https://www.jstor.org/stable/2386791

Lage J (2005) Coming into the country: New owners of ranches in the Sierra Valley, California. Masters Thesis, University of Colorado at Boulder

Lambin EF, Geist HJ (2008) Land-use and land-cover change: Local processes and global impacts. Springer Science \& Business Media, Berlin

Lambin EF, Kim H, Leape J, Lee K (2020) Scaling up solutions for a sustainability transition. One Earth 3(1):89-96. https://doi.org/10.1016/j.oneear.2020.06.010

Lambin EF, Meyfroit P (2010) Land use transitions: Socio-ecological feedback versus socio-economic change. Land Use Policy 27(2):108-118. https://doi.org/10.1016/j.landusepol.2009.09.003

Lambin EF, Turner BL, Geist HJ, Agbola SB, Angelsen A, Bruce JW, Coomes OT, Dirzo R, Fischer G, Folke C, George PS, Homewood K, Imbernon J, Leemans R, Li X, Moran EF, Mortimore M, Ramakrishnan PS, Richards JF, Xu J (2001) The causes of land-use and land-cover change: Moving beyond the myths. Glob Environ Change 11(4):261-269. https://doi.org/10.1016/S0959-3780(01)00007-3

Lark TJ, Spawn SA, Bougie M, Gibbs HK (2020) Cropland expansion in the United States produces marginal yields at high costs to wildlife. Nat Commun 11(1):4295. https://doi.org/10.1038/s41467-020$18045-z$

Liffmann RH, Huntsinger L, Forero LC (2000) To ranch or not to ranch: Home on the urban range? J Range Manage 53(4):362-370. https://doi.org/10.2307/4003745 
Lomba A, Moreira F, Klimek S, Jongman RH, Sullivan C, Moran J, Poux X, Honrado JP, Pinto-Correia T, Plieninger T, McCracken DI (2020) Back to the future: Rethinking socioecological systems underlying high nature value farmlands. Front Ecol Environ 18(1):36-42. https://doi.org/10.1002/fee.2116

Lubell MN, Cutts BB, Roche LM, Hamilton M, Derner JD, Kachergis E, Tate KW (2013) Conservation program participation and adaptive rangeland decision-making. Rangel Ecol Manag 66(6):609-620. https://doi.org/10.2111/REM-D-13-00025.1

Maestas JD, Knight RL, Gilgert WC (2003) Biodiversity across a rural land-use gradient. Conserv Biol. https://doi.org/10.1046/j.1523-1739.2003.02371.x

[dataset] Manson S, Schroeder J, Van Riper D, Kugler T, Ruggles S (2020) IPUMS national historical geographic information system: Version 15.0. Minneapolis, MN: IPUMS.

http://doi.org/10.18128/D050.V15.0

Mastrangelo ME, Gavin MC (2012) Trade-offs between cattle production and bird conservation in an agricultural frontier of the Gran Chaco of Argentina. Conserv Biol 26(6):1040-1051.

https://doi.org/10.1111/j.1523-1739.2012.01904.x

McBride WD, Matthews K Jr (2011) The diverse structure and organization of US beef cow-calf farms. In: EIB-73. USDA Econ. Res. Serv. Economic Information Bulletin No. 73. DIANE Publishing, Darby

Merenlender AM, Huntsinger L, Guthey G, Fairfax SK (2004) Land trusts and conservation easements: who is conserving what for whom? Conserv Biol 18(1):65-76. https://doi.org/10.1111/j.15231739.2004.00401.x

Mustard JF, Defries RS, Fisher T, Moran EF (2007) Land-use and land-cover change pathways and impacts. In: Gutman G, Janetos AC, Justice CO, Moran EF, Mustard JF, Ronald RR, Skole D, Turner BL, Cochrane MA (eds) Land Change Science: Observing, Monitoring and Understanding Trajectories of Change on the Earth's Surface, 1st edn. Springer Science \& Business Media, Berlin

Myers N, Mittermeier RA, Mittermeier CG, da Fonseca GAB, Kent J (2000) Biodiversity hotspots for conservation priorities. Nature 403:853-858. https://doi.org/10.1038/35002501

Nerlekar AN, Veldman JW (2020) High plant diversity and slow assembly of old-growth grasslands. PNAS 117(31):18550-18556. https://doi.org/10.1073/pnas.1922266117

Nolte C, Meyer SR, Sims KRE, Thompson JR (2019) Voluntary, permanent land protection reduces forest loss and development in a rural-urban landscape. Conserv Lett e12649.

https://doi.org/10.1111/conl.12649

Ostrom E, Cox M (2010) Moving beyond panaceas: A multi-tiered diagnostic approach for socialecological analysis. Environ Conserv 37(04):451-463. https://doi.org/10.1017/S0376892910000834 
Peco B, Sánchez AM, Azcárate FM (2006) Abandonment in grazing systems: Consequences for vegetation and soil. Agric Ecosyst Environ 113(1-4):284-294.

https://doi.org/10.1016/j.agee.2005.09.017

Petucco C, Abildtrup J, Stenger A (2015) Influences of nonindustrial private forest landowners' management priorities on the timber harvest decision-A case study in France. J Forest Econ 21:152166. https://doi.org/10.1016/j.jfe.2015.07.001

[PFT] Pacific Forest Trust (2011) Public-private partnership conserves Sierra Valley ranches. https://www.pacificforest.org/public-private-partnership-conserves-sierra-valley-ranches

Plieninger T, Ferranto S, Huntsinger L, Kelly M, Getz C (2012) Appreciation, use, and management of biodiversity and ecosystem services in California's working landscapes. Environ Manage 50:427-440. https://doi.org/10.1007/s00267-012-9900-z

Plieninger T, Hui C, Gaertner M, Huntsinger L (2014) The impact of land abandonment on species richness and abundance in the Mediterranean Basin: A Meta-Analysis. PLoS ONE 9(5):1-12. https://doi.org/10.1371/journal.pone.0098355

Ploch LA (1978) The reversal in migration patterns-some rural development consequences. Rural Sociol 43(2):293

Plumas Audubon (2008) Important bird Areas: Sierra Valley. https://www.audubon.org/important-birdareas/sierra-valley

Renting H, Rossing WAH, Groot JCJ, Van der Ploeg JD, Laurent C, Perraud D, Stobbelaar DJ, Van Ittersum MK (2009) Exploring multifunctional agriculture: A review of conceptual approaches and prospects for an integrative transitional framework. J Environ Manage 90(Supplement 2):S112-S123.

https://doi.org/10.1016/j.jenvman.2008.11.014

Rindfuss RR, Entwisle B, Walsh SJ, Mena CF, Erlien CM, Gray CL (2007) Frontier land use change: synthesis, challenges, and next steps. Ann Assoc Am Geogr 97(4):739-754.

https://doi.org/10.1111/j.1467-8306.2007.00580.x

Roche LM, Schohr TK, Derner JD, Lubell MN, Cutts BB, Kachergis E, Eviner VT, Tate KW (2015) Sustaining working rangelands: Insights from rancher decision making. Rangeland Ecol Manag 68(5). https://doi.org/10.1016/j.rama.2015.07.006

Roche LM (2016) Adaptive rangeland decision-making and coping with drought. Sustainability-Basel 8(12). https://doi.org/10.3390/su8121334

Rosenberg KV, Dokter AM, Blancher PJ, Sauer JR, Smith AC, Smith PA, Stanton JC, Panjabi A, Helft L, Parr M, Marra PP (2019) Decline of the North American avifauna. Science eaaw1313.

https://doi.org/10.1126/science.aaw1313

Page 28/37 
Runge CA, Plantinga AJ, Larsen AE, Naugle DE, Helmstedt KJ, Polasky S, Donnelly JP, Smith JT, Lark TJ, Lawler JJ, Martinuzzi S, Fargione J (2019) Unintended habitat loss on private land from grazing restrictions on public rangelands. Journal of Appl Ecol 56(1):52-62. https://doi.org/10.1111/13652664.13271

Sala OE, Chapin FS III, Armesto JJ, Berlow E, Bloomfield J, Dirzo R, Huber-Sanwald E, Huenneke LF, Jackson RB, Kinzig A, Leemans R, Lodge DM, Mooney HA, Oesterheld M, Poff NL, Sykes MT, Walker BH, Walker M, Wall DH (2000) Global biodiversity scenarios for the year 2100. Science 287(5459):17701774. https://doi.org/10.1126/science.287.5459.1770

Sayre NF (2004) Viewpoint: The need for qualitative research to understand ranch management. J Range Manage 57(6):668. https://doi.org/10.2307/4004026

Schaich H, Plieninger T (2013) Land ownership drives stand structure and carbon storage of deciduous temperate forests. Forest Ecol Manag 305:146-157. https://doi.org/10.1016/j.foreco.2013.05.013

Sinnott JJ (1976) Sierra Valley: Jewel of the Sierras. California Traveler, Inc., Pioneer

Smith AH, Martin WE (1972) Socioeconomic behavior of cattle ranchers, with implications for rural community development in the West. Am J Agr Econ 54:217. https://doi.org/10.2307/1238704

Spiegal S, Huntsinger L, Hopkinson P, Bartolome JW (2016) Range ecosystems. In: Ecosystems of California. University of California Press, Berkeley, pp 835-864

Starrs P, Huntsinger L (2012) Natural resources and sustainability. In: Vasey DE, Fredericks SE, Thompson S, Shen L (eds) Berkshire Encyclopedia of Sustainability. Berkshire Publishing, Great Barrington, pp 388392

Stuth JW, Conner JR, Heitschmidt RK (1991) Chap. 10: The decision-making environment and planning paradigm. In: Stuth JW, Heitschmidt RK (eds) Grazing management: An ecological perspective. Timber Press, Oregon. https://cnrit.tamu.edu/rlem/textbook/Chapter10.htm

Sun F, Berg N, Hall A, Schwartz M, Walton D (2019) Understanding end-of-century snowpack changes over California's Sierra Nevada. Geophys Res Lett 46(2):933-943. https://doi.org/10.1029/2018GL080362

Tejeda HA, Kim M-K, Feuz DM (2019) Impact of alfalfa exports surge on dairy and feed markets in California. Journal of Agribusiness 37(1):23-34. https://doi.org/10.22004/ag.econ.302467

[UC ANR] University of California Division of Agriculture and Natural Resources (2007) Beef care practices. Publication No. 8257. Oakland, California

[USDA-FAS] USDA Foreign Agricultural Service (2019) Beef and cattle. https://www.fas.usda.gov/commodities/beef-and-cattle 
[dataset] [USDA-NASS] USDA National Agricultural Statistics Service (2019) USDA National Agricultural Statistics Service Cropland Data Layer. http://nassgeodata.gmu.edu/CropScape

Waechter SA, Ekness Norton T, n.d. Archaeology and prehistory in Sierra Valley. Far Western Anthropological Research Group, Inc., Redding, California. https://farwestern.com/wordpress/wpcontent/uploads/2014/05/Step_Back_In_Time.pdf

Walker PA, Marvin SJ, Fortmann LP (2003) Landscape changes in Nevada County reflect social and ecological transitions. Calif Agr 57(4):115-121. https://doi.org/10.3733/ca.v057n04p115

Walker P, Fortmann L (2003) Whose landscape? A political ecology of the "exurban". Sierra Cult Geog 10(4):469-491. https://doi.org/10.1191/1474474003eu285oa

Weeks D, Wieslander AE, Josephson HR, Hill CL (1943) Land utilization in the Northern Sierra Nevada. University of California Press, Berkeley

Wetzel WC, Lacher IL, Swezey DS, Moffitt SE, Manning DT (2012) Analysis reveals potential rangeland impacts if Williamson Act eliminated. Calif Agr 66(4):131-136. https://doi.org/10.3733/ca.v066n04p131

White R, Murray S, Rohweder M (2000) Pilot analysis of global ecosystems: Grassland ecosystems. World Resources Institute. https://www.wri.org/publication/pilot-analysis-global-ecosystems-grasslandecosystems

Wilmer H, Augustine DJ, Derner JD, Fernández-Giménez ME, Briske DD, Roche LM, Tate KW, Miller KE (2018) Diverse management strategies produce similar ecological outcomes on ranches in Western Great Plains: Social-Ecological Assessment. Rangeland Ecol Manag 71(5): 626-636. Scopus. https://doi.org/10.1016/j.rama.2017.08.001

Wilmer H, Fernández-Giménez ME (2015) Rethinking rancher decision-making: A grounded theory of ranching approaches to drought and succession management. The Rangeland Journal 37(5):517-528. https://doi.org/10.1071/RJ15017

Wu J (2013) Landscape sustainability science: ecosystem services and human well-being in changing landscapes. Landscape Ecol 28:999-1023. https://doi.org/10.1007/s10980-013-9894-9

Wu J (2021) Landscape sustainability science (II): core questions and key approaches. Landscape Ecol 36:2453-2485. https://doi.org/10.1007/s10980-021-01245-3

Yahdjian L, Sala OE, Havstad KM (2015) Rangeland ecosystem services: Shifting focus from supply to reconciling supply and demand. Front Ecol Environ 13(1):44-51. https://doi.org/10.1890/140156

Yost M, Allen N, Creech E, Putnam D, Gale J, Shewmaker G (2020) Ten reasons why alfalfa is highly suitable for the West. Utah State University Agricultural Extension.

https://digitalcommons.usu.edu/cgi/viewcontent.cgi?article=3100\&context=extension_curall 
Zaccaria D, Carrillo-Cobo MT, Montazar A, Putnam D, Bali K (2017) Assessing the viability of sub-surface drip irrigation for resource-efficient alfalfa production in Central and Southern California. Water 9:837. http://dx.doi.org/10.3390/w9110837

\section{Figures}

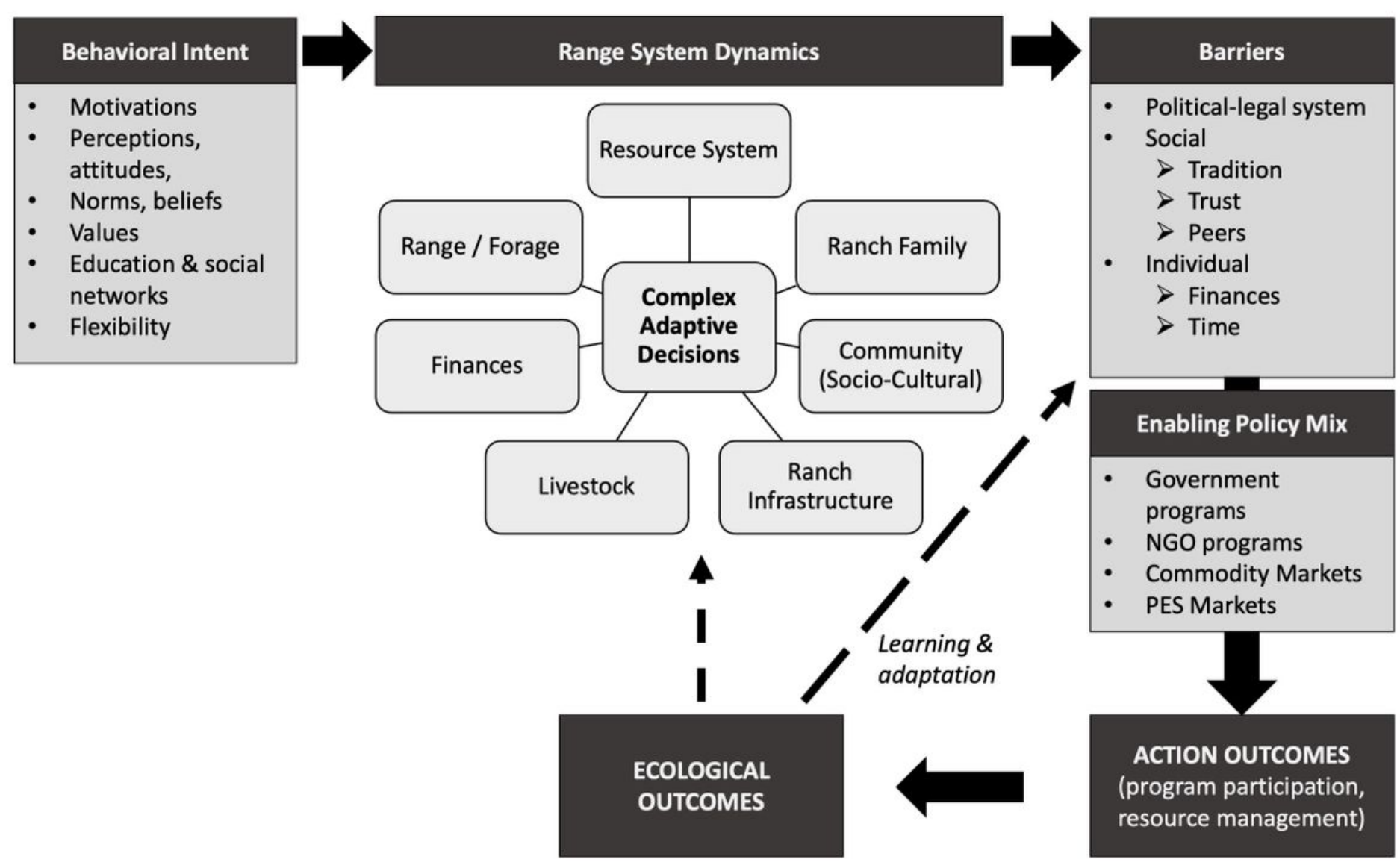

\section{Figure 1}

Landowner decision-making within rangeland social-ecological systems This model aggregates findings from Gentner and Tanaka (2002), Kennedy and Brunson (2002), Sayre (2004), Didier and Brunson (2004), and Farley et al. (2007), Lubell et al. (2013), Brain et al. (2014), Wilmer and Fernández-Giménez (2015), Roche et al. $(2015,2016)$, and Aoyama and Huntsinger (2019) 

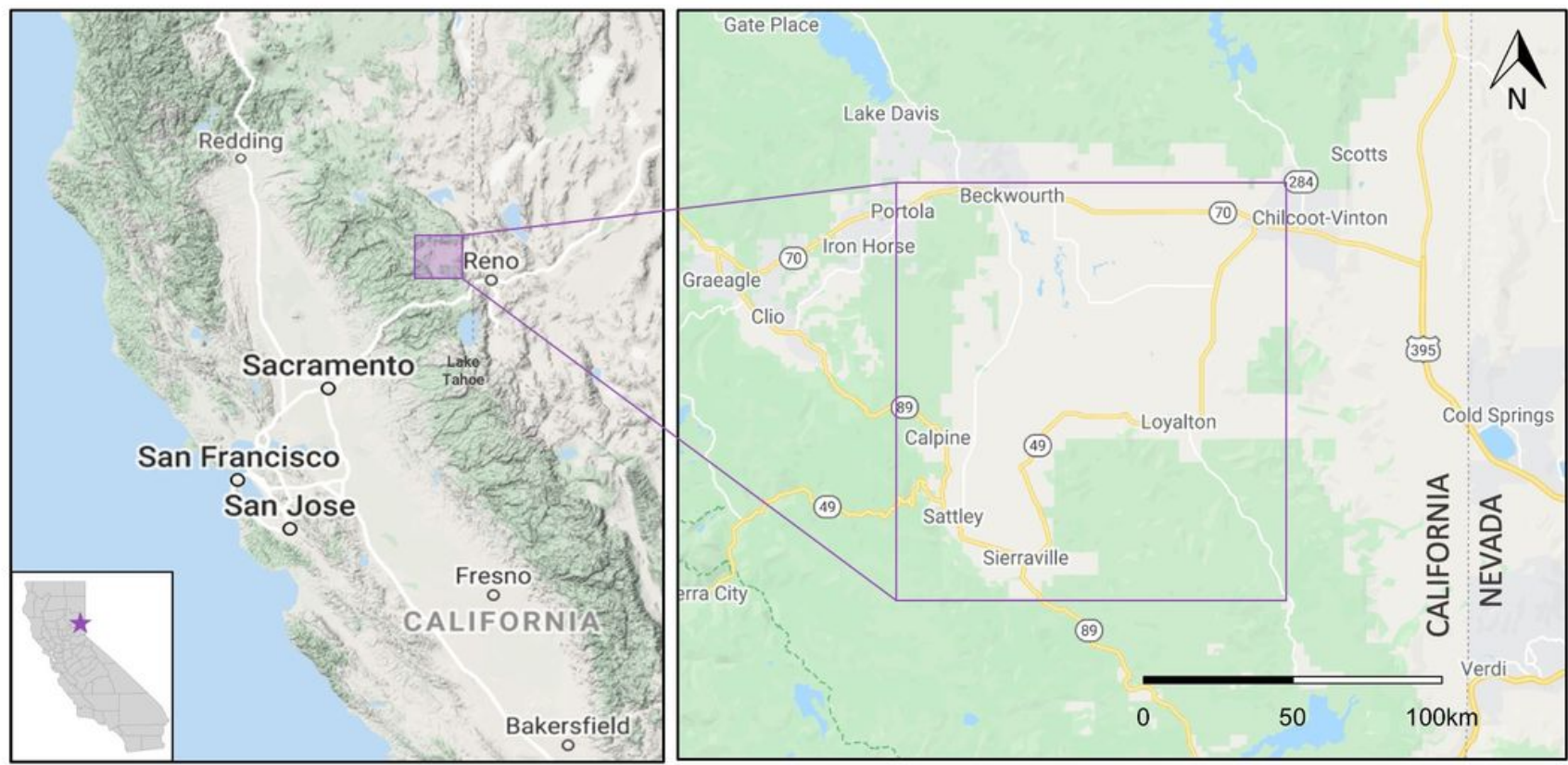

Case Study Site

Figure 2

Case Study Site: Sierra Valley, California Visualized with ggmap (Kahle and Wickham, 2013)

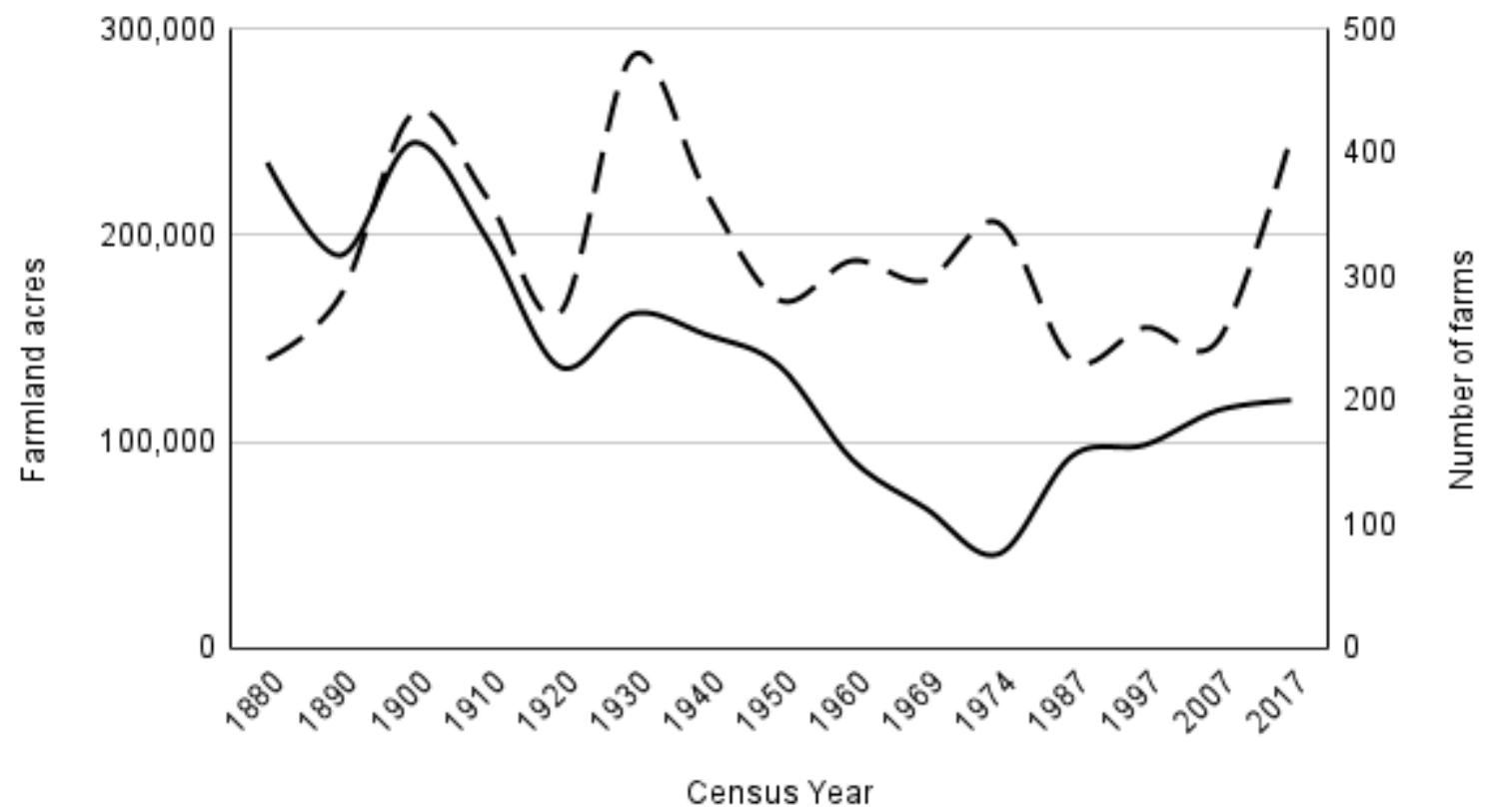

Figure 3 
Farmland trends in Plumas \& Sierra Counties, CA (1880-2012) Data from the USDA-NASS Census of Agriculture (Haines et al. 2018). Plumas and Sierra counties have retained their agricultural heritage since European settlement, with some fluctuation in farmland acreage and number of farms over time
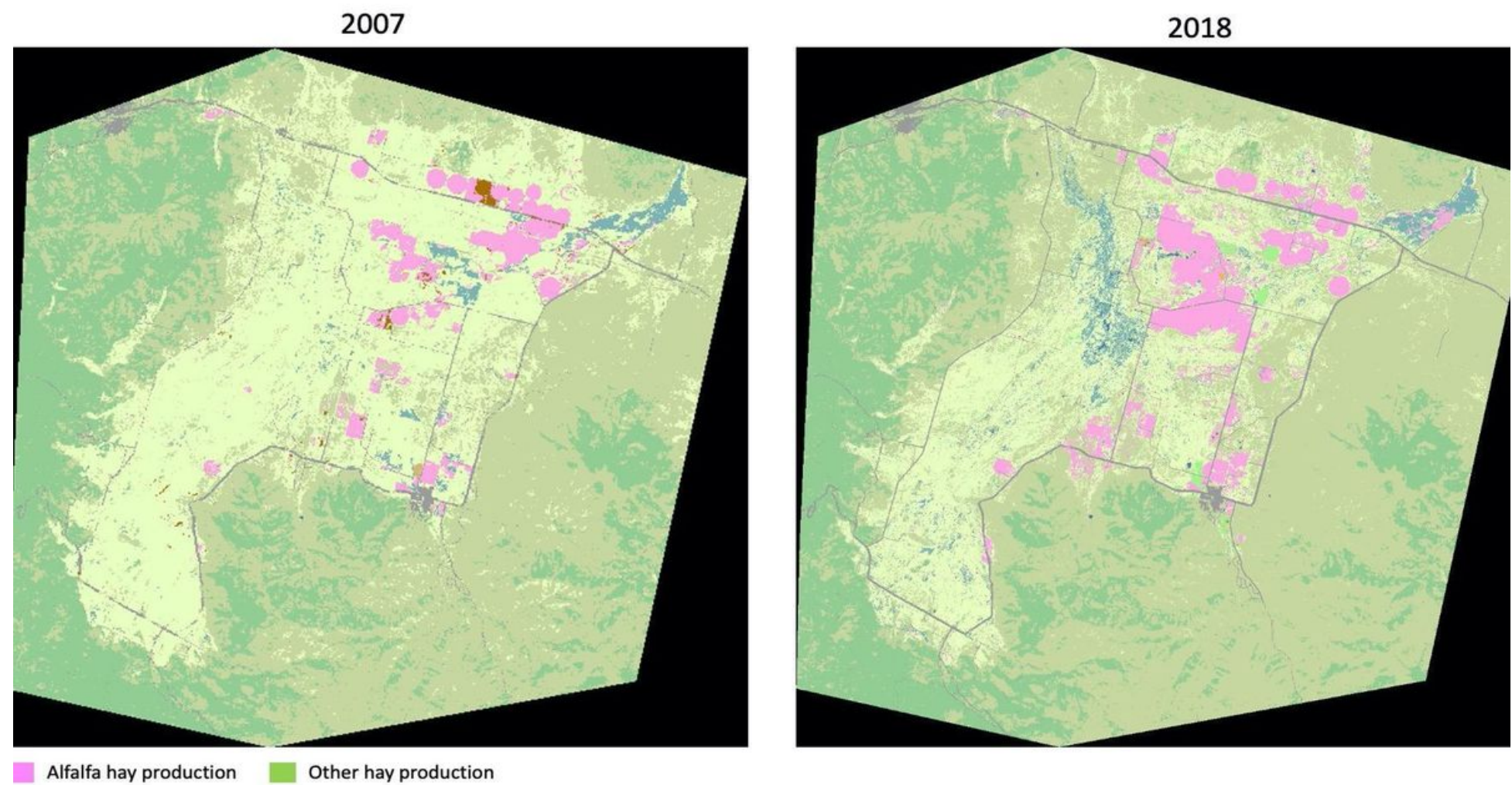

Alfalfa hay production

Other hay production

Figure 4

Increase in alfalfa production in Sierra Valley, 2007 and 2018 Data from Boryan et al. (2011) and USDANASS (2019) 


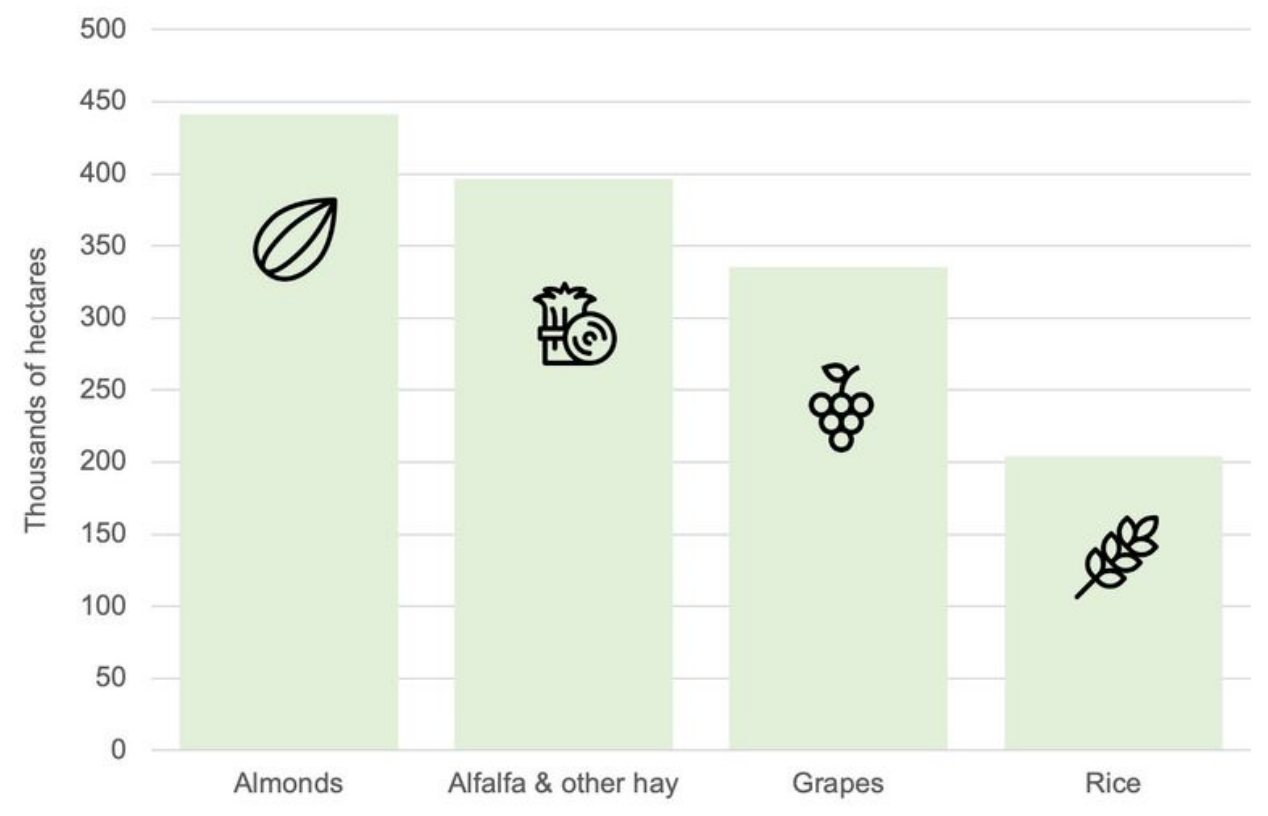

Figure 5

California leading agricultural products by land area, 2018 Data from CDFA (2019); images from freepik@flaticon

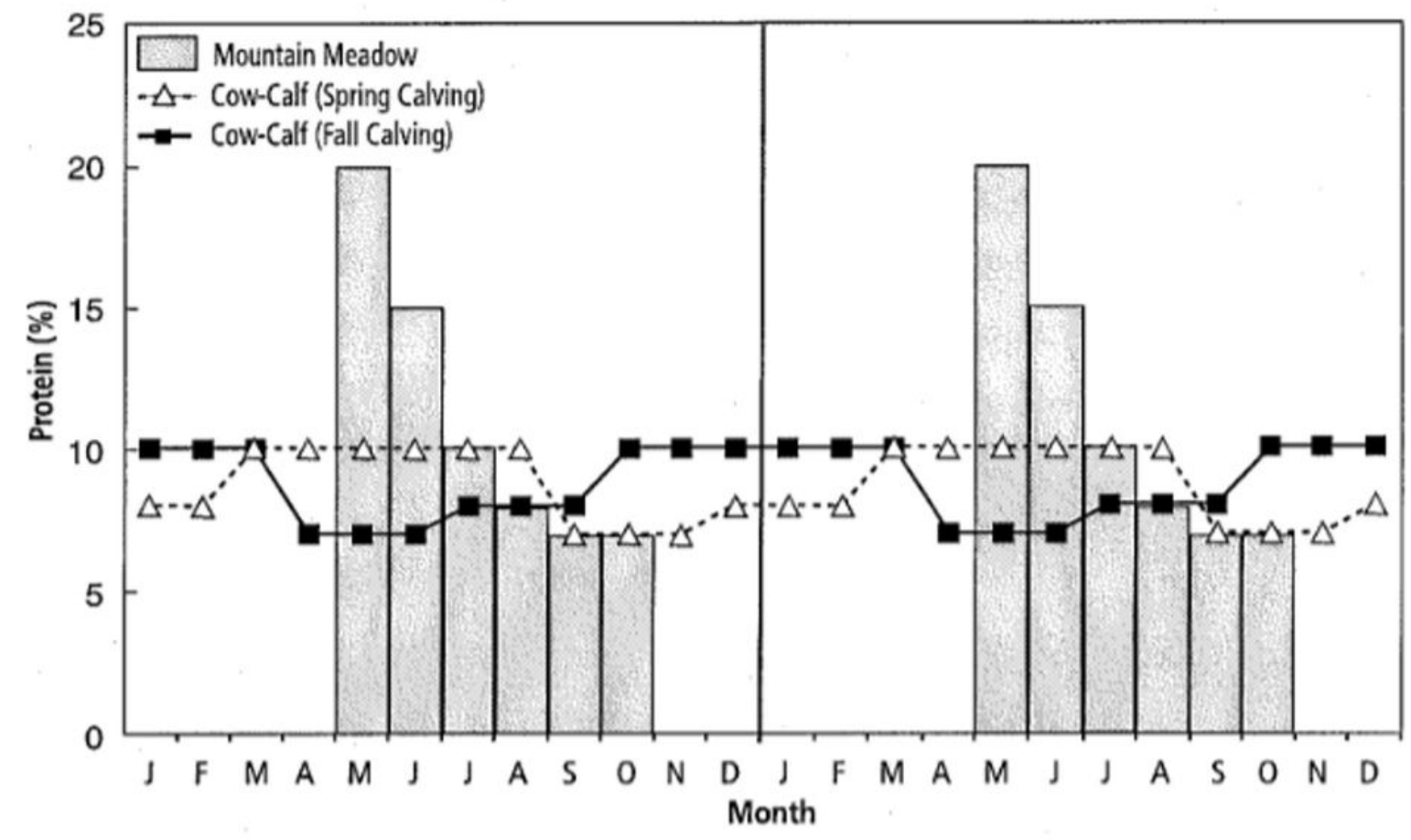




\section{Figure 6}

Fluctuations in herd demand and protein content on mountain meadows of the West Side Sierra Nevada Conservation easements that limit spring and early summer grazing can be challenging for ranchers, as the most nutritious forage is available in May and June. Lines represent herd demand for protein content and bars represent protein content on mountain meadows. Source: University of California Agriculture and Natural Resources (George et al. 2001)

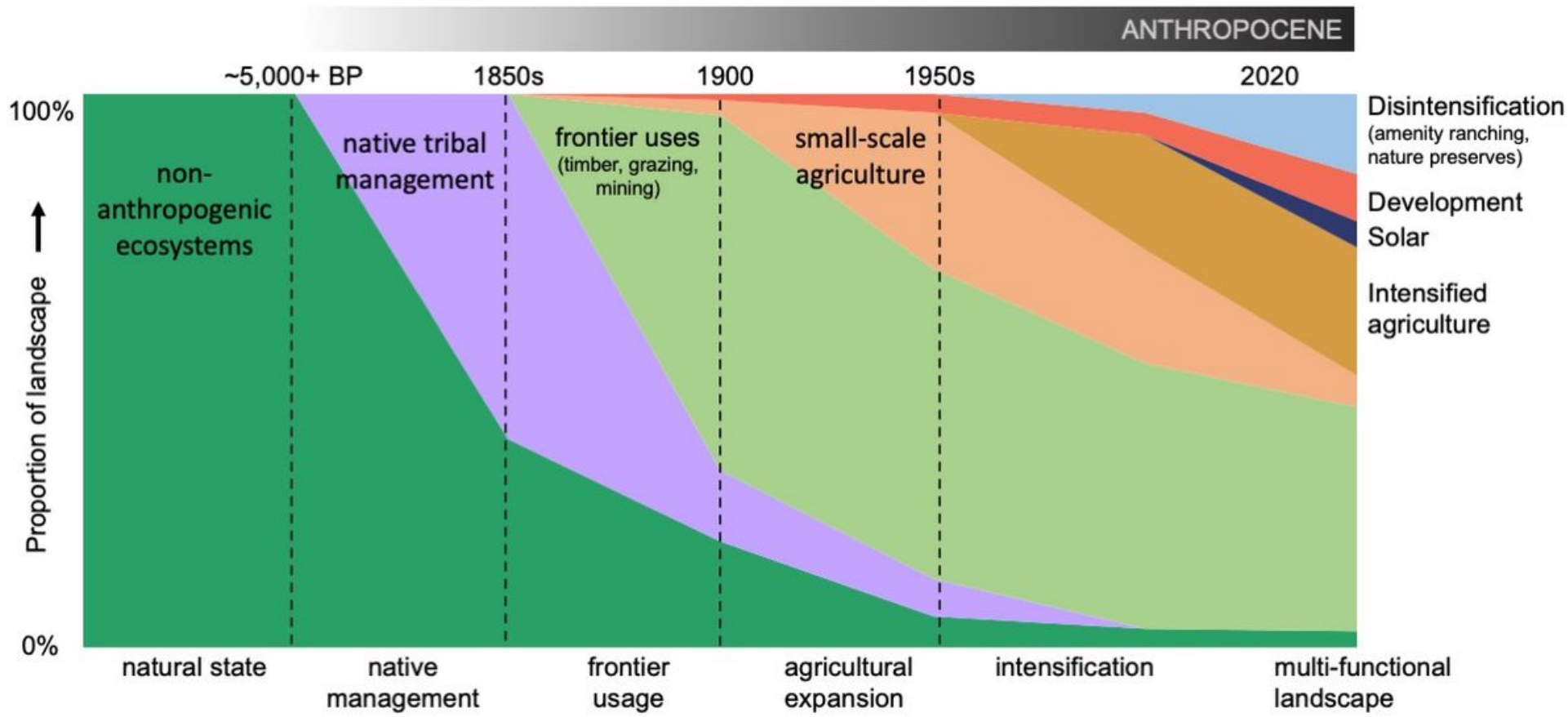

Stage in land use transition

\section{Figure 7}

Land use transition pathways framework applied to Sierra Valley, California The land use transition pathways framework adapted from Foley et al. (2005), DeFries et al. (2004), Mustard et al. (2007). Several factors have been added to the framework in the context of Sierra Valley, including amenity landownership, solar development, extensive grazing (an ongoing type of less intensive frontier land use), and native management. Sierra Valley has a long history of use and management by Native Americans; archeological evidence supports native tribes residing in the area for at least 5,000 years (Waechter and Ekness Norton, n.d.) and being in California for at least 19,000 years (Klein 1995) 


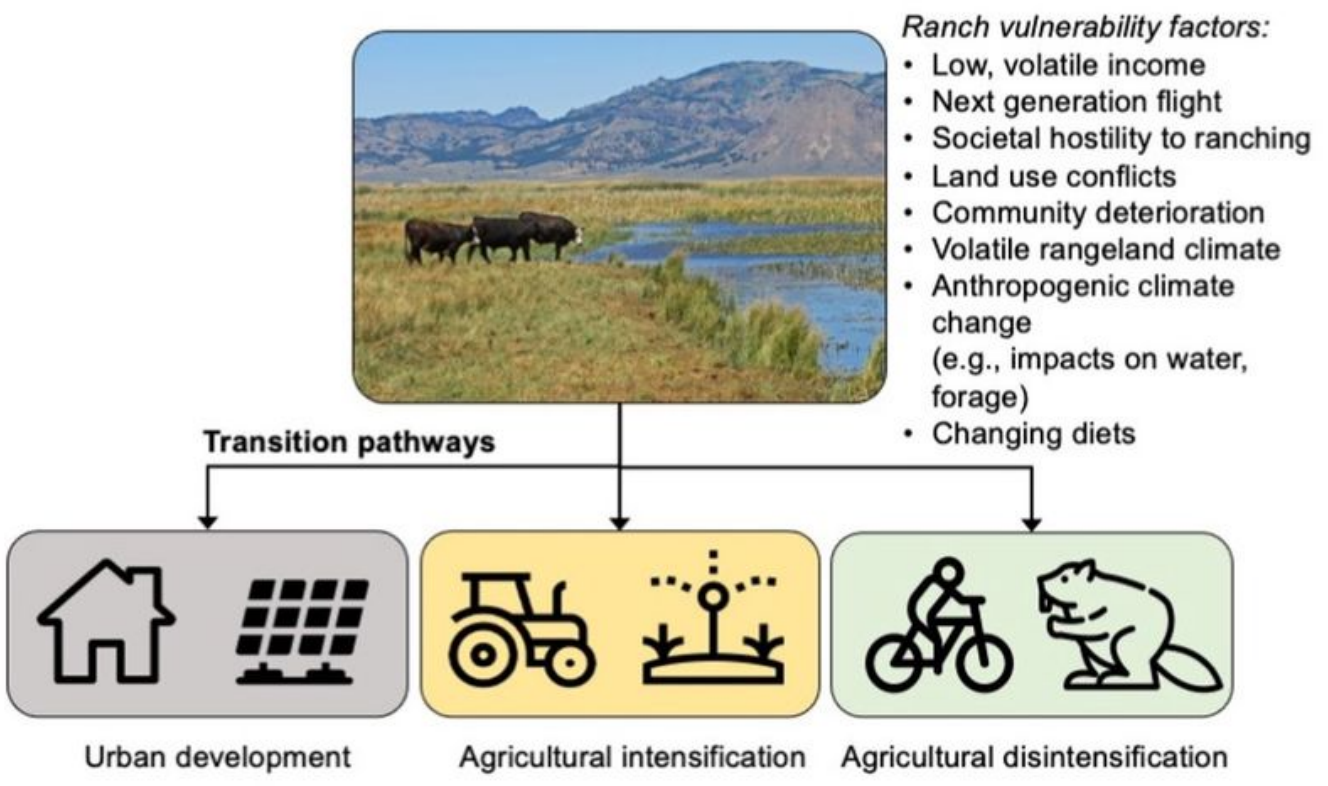

Residential \& solar development

Drivers

Constraints

- Ranch income diversification

- Landowner access to capital

- Land use planning (e.g., county General

- Amenity migration Plans, state agricultural land protection policies)

- Regulatory burdens on agriculture

- Renewable energy policy

\section{Agricultural intensification}

\section{Drivers}

- Ranch income diversification

- Water development

- Landowner access to capital

- Irrigation technology

- Forage loss at lower elevations (e.g., due to residential development, wildfire)

- Demand for irrigated crops (e.g., alfalfa hay)

\section{Constraints}

- Land use planning (e.g., local zoning)

- Conservation easements

- Climate change perspectives

- Amenity migration

- Public lands access

- State agriculture \& water policy

\section{Agricultural disintensification}

Drivers

- Amenity migration

- Societal interest in conservation and rewilding

- Regulatory burdens on agriculture

- Endangered species policy

\section{Figure 8}

Drivers and constraints of land use transition pathways in Sierra Valley Proximal factors are shown in bold, and distal factors in non-bold font. This figure builds on the transition pathways framework (Foley et al. 2005; DeFries et al. 2004; Mustard et al. 2007) and social-ecological systems frameworks developed by Ostrom and Cox (2010) and Charnley et al. (2018). Photo credits: Judy Gallagher@flickr, freepik@flaticon.com 


\section{Supplementary Files}

This is a list of supplementary files associated with this preprint. Click to download.

- Supplement1.xIsx

- Supplement2.docx 